\title{
LOS EJEMPLOS HAGIOGRÁFICOS Y LEGENDARIOS FEMENINOS Y ALGUNOS ELEMENTOS DEL CULTO A LAS SANTAS MUJERES EN LA OBRA DE SAN GREGORIO MAGNO*
}

La mujer, junto con el hombre, en una complementariedad mútua, es creada a imagen de Dios y forma, junto con el hombre, el culmen de la creación divina ${ }^{1}$. El Antiguo Testamento presenta para nosotros una imagen de la igualdad y unión interpersonal entre la mujer y el hombre en sus primeros momentos $^{2}$. Sin embargo, desde una perspectiva general notamos una inferioridad de la mujer frente al hombre. La continuación de esta línea la encontramos en el Nuevo Testamento, especialmente en los escritos de S. Pablo ${ }^{3}$. El punto clave que predomina todas las perspectivas bíblicas es la actitud de Jesucristo, abierto a la mujer.

La visión bíblica junto con las influencias socioculturales del mundo antiguo abrió las puertas para un campo amplio de la interpretación del papel de la mujer en la vida de la Iglesia cristiana. De las figuras femeninas bíblicas indudablemente dos - Eva y María - son las que más influyeron en la concepción de la mujer formulada por los Padres de la Iglesia ${ }^{4}$. Eva generalmente es

* Este artículo es el segundo capítulo de mi tesis doctoral titulada La mujer en la vida y el pensamiento de San Gregorio Magno (540-604) y dirigida por el Prof. Dr. D. Domingo RamosLissón. Me resta aquí dar gracias por su ayuda inestimable.

1 Cfr. Gn 1, 27.

${ }^{2}$ Cfr. Corporeidad y sexualidad humanas en los relatos bíblicos de la creación, en: AA.VV. [Autores varios], Masculinidad y feminidad en el mundo de la Biblia, Pamplona 1989, 30-37.

${ }^{3}$ Cfr. E. Lipiński, Femme, en: AA.VV., Dictionaire encyclopedique de la Bible, Turnhout 1987, 472-474; ibidem una amplia bibliografía sobre el papel de la mujer en el mundo bíblico y en las sociedades antiguas.

${ }^{4}$ Para ver más profunda elaboración sobre la mariología patrística, vid. J.A. De Aldama, María en la patrística de los siglos I y II, Madrid 1970; S. Felici (red.), La mariologia nella catechesi dei Padri (etá prenicena); Roma 1989; E. Peretto, Mariologia patristica, en: A. Quacquarelli (red.), Complementi interdisciplinari di patrologia, Roma 1989, 697-756; G.I. Söll, María, DPAC [Diccionario patrístico y de la antigüedad cristiana, Salamanca 1991] 1359-1363, ibidem amplia literatura. Algunos de los textos más interesantes gregorianos sobre este tema son editados en: S. Alvarez Campos, Corpus Marianum Patristicum, VI, Burgos 1981, 391-401; D. Casagrande, Enchiridion Marianum biblicum patristicum, Roma 1974, 1242-1250. Merece la pena ver también: M. Doucet, La Vierge Mére de Dieu dans la théologie de saint Grégoire le Grand, BLE 84 (1983) 163. 
vista por los Padres como la mujer en su situación existencial de inferioridad, y María como la meta hacia la que, precisamente esta mujer, considerada en inferioridad - cuando no asociada a un signo claramente negativo - tiende y con la que debe identificarse ${ }^{5}$. La época patrística ha dado para la posterioridad la visión de la mujer muy diferente. Por un lado podemos encontrar las comparaciones entre la mujer y la Iglesia y por otro tan sorprendentes opiniones como la de Tertuliano que llama a Eva ,la puerta del diablo” y „la primera violadora de la ley divina" . Al lado de esas dos personas - pilares vemos en la literatura cristiana primitiva también un grupo de muchísimas mujeres de la Biblia comentadas por los teólogos de la era patrística, así como también un gran número de referencias al mundo femenino.

No es dificil adivinar que no sólo las mujeres bíblicas constituyeron un punto de interés para los antiguos autores cristianos. Se puede confirmar con certeza la opinión de Mara que dice: „Los Padres estudian ampliamente las características de la mujer en los diversos estados de virgen, esposa, madre, viuda, recogiendo tanto los modelos conocidos en la cultura pagana como los propios de la Escritura o aquellos que ya desde los primeros siglos se presentaban como nuevos ejemplos de la mujer como Mónica, Nonna, Macrina, Melania [...] a las cuales se podía referir en contextos concretos y actuales? Durante años creció entre las líneas de los escritos patrísticos una doctrina cristiana acerca de la mujer en una gama de amplias dimensiones. De ellas se ocuparon autores tan famosos como: Orígenes, Atanasio, Gregorio Niseno, Jerónimo, Juan Crisóstomo, Ambrosio, Agustín, Cipriano, o nuestro Gregorio $\mathrm{Magno}^{8}$. En la actualidad han abundado los estudios sobre la cuestión feme-

${ }^{5}$ Cfr. M.G. Mara, Mujer, DPAC II 1487-1488.

${ }^{6} \mathrm{Cfr}$. De cultu feminarum 1, 1-2, CCL 1, 343: „Et Evam te esse nescis? [...]. Tu es diaboli janua, tu es arboris illius resignatrix, tu es divinae legis prima desertrix, tu es quae cum persuasisti, quem diabolus aggredi non valuit. Tu imaginem Dei, hominem, tam facile elisisti”

7 M.G. Mara, art. cit., p. 1488.

${ }^{8}$ Gregorio Magno nació en Roma en el año 540. Allí empezó la carrera política. Cerca del año 570 ya ocupa un cargo muy elevado, es el praefectus urbi : la persona más importante en la ciudad en esos tiempos gobernado por el exarca de Ravena. Una conversión religiosa en su vida hizo que cerca del año 574 distribuyera sus bienes y se hiciese monje. En sus viejas propiedades fundó numerosos monasterios, uno en Roma y seis en Sicilia. En el año 579 fue ordenado como diácono y enviado a Constantinopla para ocupar, cerca del emperador Mauricio, el cargo de apocrisiario (legado). Después de la sexenal estancia en la capital oriental, volvió a la „ciudad eterna", donde siguió la vida monástica y se ocupaba del trabajo caritativo. En el año 590, cuando murió de peste Pelagio II, Gregorio fue elegido en su lugar y no obstante de su cerca semestral resistencia, nombrado papa. Había llevado una dinámica actividad caritativa y pastoral. Cuidó de los monasterios, mantenía una enorme correspondencia con los monarcas, también paganos. Como indudable logro se puede mencionar el envío en el año 596 de un grupo de misioneros, bajo el mando de Agustín, con intención de la evangelización de Inglaterra. Los éxitos en el campo de la política, la pastoral, liturgía y espiritualidad, así como su abundante obra, le propició el título de Grande. Sobre este tema detalladamente vid. J. Czuj, Papież Grzegorz Wielki, Warszawa 1948; 
nina en el cristianismo primitivo, tanto desde una perspectiva general, como de problemas más limitados, como el martirio de la mujer, la virginidad, la viudedad, la diaconía, etc ${ }^{9}$. Encontramos también algunas monografías dedicadas a la mujer y su papel en relación con un autor concreto ${ }^{10}$. A pesar de esos trabajos todavía podemos descubrir unas zonas menos estudiadas o que no se han profundizado suficientemente. Este es el caso de S. Gregorio Magno sobre el que discurre nuestra investigación.

Pero surge la pregunta inevitable: ¿Por qué ocuparnos del papel de la mujer en S. Gregorio Magno? Nuestra respuesta es bien precisa: siempre nos ha atraído la figura de este Pontífice, a través de las lecturas que hemos realizado de sus obras. En él exactamente podemos descubrir un resumen de la cuestión elaborada en el pensamiento cristiano durante los siglos pasados. Es también S. Gregorio Magno una de las personalidades más importantes̀ del fin de la epoca patrística que confirma Juan Pablo II en la carta apostólica Plurimum significans ${ }^{11}$. Si tomamos en cuenta la opinión de Rosik que „,no hay en el medievo obra teológica o una compilación, que no manifieste la inspiración de (este) Papa"12, sin duda podemos también afirmar que su persona y su obra tienen una parte relevante en la formación de la conciencia medieval también sobre el papel de las mujeres y constituye un puente original entre la visión de la antigüedad cristiana y la del medievo.

En todos los escritos gregorianos nos encontramos con referencias a personajes femeninos de la Biblia. San Gregorio Magno hace algunas veces un estudio muy detallado y profundo de las imágenes femeninas de la Sagrada Escritura tanto del Antiguo como del Nuevo Testamento. Al lado de las personas bíblicas, en la obra de S. Gregorio Magno encontramos también,

F.H. Dudden, Gregory the Great. His place in History and Thought, 2 vol., London 1905; V. Paronetto, Gregorio Magno. Un maestro alle origini cristiane d'Europa, Roma 1985; J. Richards, Consul of God. The Life and Times of Gregory the Great, London 1980; V. Recchia, Gregorio I Magno, DPAC I 990-995, ibidem amplia literatura.

${ }^{9}$ Basta aquí mencionar sólo algunos nuevos títulos, entre los cuales especial atención merecen los siguientes: M. Benlloch Ibarra, Mulier fortis. La mujer en las fuentes cristianas (280-313), Zaragoza 1990; E. Bautista, La mujer en la Iglesia Primitiva, Estella 1993; G. Cloke, 'This Female Man of God'. Women and spiritual power in the patristic age, AD 350-450, London 1995; F. Dupriez, La condition féminine et les Pères de l'Église Latine, Montréal 1982; R. Fabris, La femme dans l'Église Primitive, Paris 1987; F. Quere, La Femme et les Pères de l'Église, Paris 1997, etc.

${ }^{10}$ Vale la pena apuntar por lo menos estas monografías: K.E. Borresen, Subordination and Equivalence. The Nature and Role of Woman in Augustine and Thomas Aquinas, Kampen 1995; D. Gemmiti, La donna in Origene, Napoli-Roma 1996; C. Militello, Donna e Chiesa. La testimonianza di Giovanni Crisostomo, Palermo 1985.

${ }^{11}$ Cfr. Juan Pablo II, Plurimum significans (29 de junio de 1990), en: Insegnamenti di Giovanni Paolo II, Libreria Editrice Vaticana 1992, XIII/1, 1691-1696.

12 S. Rosik, Twórczość Grzegorza Wielkiego i jej wptyw na myśl średniowiecza, RTK 21 (1974) nr 3, 70: „Nie ma w średniowieczu dzieła teologicznego czy kompilacji, które nie ujawniłoby inspiracji (tego) Papieża". 
un grupo suficientemente numeroso de las santas extrabiblicas. La existencia y la vida de algunas de ellas están fuertemente atestiguadas por otras fuentes, aparte de los escritos gregorianos; algunas están sólo mencionadas, otras pertenecen más a las leyendas piadosas que a la verdadera historia ${ }^{13}$. Nosotros limitaremos aquí nuestra visión solamente a estos ejemplos extrabíblicos ${ }^{14}$. Para ello vamos a examinar la producción literaria de nuestro Autor, fijándonos especialmente en obras, como las Homiliae in Evangelia y los Dialogi: la obra en una gran parte legendaria pero que contiene a la vez datos biográficos muy interesantes sobre algunas personas santas y sirve como una de las fuentes importantes para nuestro estudio. No podemos hacer caso omiso de otras obras, como Registrum epistolarum, los comentarios bíblicos (Moralia in Iob - la más grande obra gregoriana de treinta y cinco libros, en los que comenta el Libro de Job, Expositio super Cantica Canticorum e In I Librum Regum expositionum libri VI) y otras homilías (Homiliae in Ezechielem). En la relación con su famosa Regula pastoralis podemos señalar la escasez de textos sobre la mujer que presenta, tal vez por tratarse de una obra dirigida a los pastores de la Iglesia ${ }^{15}$.

En relación con el estado de la investigación, podemos consignar aquí algunos trabajos que se refieren a los problemas parciales. Merece la pena apuntar un corto artículo de Grün sobre la mujer en los Diálogos ${ }^{16}$. También debemos mencionar los artículos sobre la visión gregoriana hagiográfica. Aquí el primer lugar lo ocupa, sin duda ninguna, S. Escolástica. Podemos afirmar que ese tema es más popular entre los investigadores y tenemos hasta ahora por lo menos once títulos ${ }^{17}$. De nuestro registro tampoco podemos olvidar un estudio dedicado a S. Silvia ${ }^{18}$.

${ }^{13}$ Gracias a los escritos gregorianos algunas de esas personas entraron al Martyrologium romanum. Esta cuestión está tratada ampliamente en: B. De Gaiffier, Les héroes des Dialogues de Grégoire le Grand inscrits au nombre des saints. Appéndice: A propos des saints du livre II des Dialogues, AnBol 83 (1965) 53-74.

${ }^{14}$ Sobre el tema de las mujeres bíblicas preparamos actualmente una publicación que estará editada en otro tiempo.

15 Es nuestro propósito utilizar siempre que sea posible ediciones críticas de las obras de nuestro Autor, especialmente las publicadas en el CCL 140-144 y SCh 32 bis, 212, 221, 251, 260, $265,314,327,351,360,370-371$.

${ }^{16}$ Cfr. A. Grün, Der Weg der Selbstwerdung der Frau nach den Dialogen Gregors, ,Erbe und Auftrag" 64 (1988) 97-106.

${ }^{17}$ Cfr. G.M. Colombas, El milagro de santa Escolástica. Dos lecturas de san Gregorio Magno, Diálogos II, 33 y 34, ,Nova et Vetera” 11 (1981) 29-37; J.H. Wansbrough, St. Gregory's Intention in the Stories of St Scholastica and St Benedict, , Revue Bénédictine” 75 (1965) 145-151; A. De Vogüé, La rencontre de Benoit et de Scholastique. Essai d'interprétation, ,Revue d'histoire de la spiritualité" 48 (1972). La lista completa la podemos encontrar en: R. Godding, Bibliografia di Gregorio Magno (1890-1989), Roma 1990.

${ }_{18}$ Cfr. E. Wuescher-Becchi, Santa Silvia, madre di san Gregorio e le sue memorie, „Rassegna gregoriana" 3 (1904) 59-70. 
En cuanto al método empleado, hemos de decir, que en una primera aproximación hemos propuesto hacer un trabajo directamente sobre las fuentes, con un análisis de los textos, para después establecer una síntesis del pensamiento gregoriano en cada punto concreto estudiado. De acuerdo con el material recogido hemos dividido el trabajo en seis puntos: 1. Las santas de la familia gregoriana, 2. Sta. Escolástica - la primacía del amor, 3. Sta. Felicidad y Sta. Inés - la gloria del martirio, 4. Los ejemplos menos destacados, 5. Los ejemplos legendarios, 6 . Algunos otros elementos del culto a las santas.

\section{LAS SANTAS DE LA FAMILIA GREGORIANA}

Sin duda la familia es el primer lugar donde se imparte la educación cristiana, „la primera escuela del amor y de la solidaridad; la primera escuela de todas las virtudes humanas y cristianas" ${ }^{\text {19 }}$. Por eso en nuestra dimensión debemos tomar en cuenta a las santas de la familia gregoriana, aunque no hay muchos escritos, donde se las menciona.

1. Sta. Silvia, la madre de S. Gregorio. Como la mujer de más importante influencia en el crecimiento de las virtudes cristianas vividas por Gregorio, aparece madre. Es muy raro que Gregorio no mencione en concreto a su madre en ningún escrito, ni siquiera por su nombre. Las únicas palabras de Gregorio sobre este tema son las siguientes: ,...eadem hora ejus exitus multi viri et feminae ejus lectulum circumsteterunt, inter quas mater mea quoque adfuit" ${ }^{20}$. Es la descripción del momento de la muerte de su tía Tarsilia. Hablando en otra ocasión sobre la misma escena ya no menciona su persona ${ }^{21}$.

Sobre Sta. Silvia, sólo tenemos algunas pequeñas notas y un corto artículo antiguo de dificil consulta ${ }^{22}$. Según la tradición se llamaba Silvia y la santa Iglesia la pone en el número de los santos y la venera el día 3 de noviembre $^{23}$. Los datos que tenemos sobre esta santa son muy parciales. No conocemos la fecha de su nacimiento y la de su muerte nos es incierta, pues se dan grandes divergencias: la Bibliotheca Sanctorum la sitúa entre los años 592/594, mientras que otros mencionan el año $572^{24}$.

19 Juan Pablo II, La famiglia e una comunità di vita aperta alla vita (homilía en Civitavecchia, 19. 03. 1987), en: Insegnamenti di Giovanni Paolo II, X 1, Vaticano 1987, 625: ,... la famiglia deve essere la prima scuola della dell'amore e della solidarietà. La prima scuola di tutte le virtù umane e cristiane".

${ }^{20}$ Homiliae in Evangelia II 38, 15, PL 76, 1291.

${ }^{21}$ Cfr. Dialogi de vita et miraculis Patrum Italicorum IV 16, 2, SCh 265, 68.

${ }^{22}$ E. Wuescher-Becchi, Santa Silvia, madre di san Gregorio e le sue memorie, art. cit., col. 59-70.

${ }^{23}$ Cfr. AA. VV., Dix mille Saints. Dictionnaire hagiographique, Turnhout 1991, 461.

${ }^{24}$ Cfr. J.B. Proja, Silvia, BS XI 1082; Dix mille Saints, 461. 
La santa está mencionada nominalmente en Vita Gregorii escrita por Pablo Diácono y en la otra obra con el mismo título de Juan Diácono ${ }^{25}$. El primero había escrito su biografía en el siglo VIII sacando las informaciones probablemente de los escritos de Beda y del Liber pontificalis. El otro, que escribió la obra en el fin del siglo IX, tomó como fuente a la Vita de Pablo y algunas otras obras $^{26}$. En las biografías la verdad está mezclada con la leyenda, especialmente en la de Juan. Merece la pena apuntar que Juan la llama beata atestiguando en ese modo la veneración que gozaba en la Iglesia. Juan es tan detallista que apunta que Silvia, por ejemplo, tenía costumbre de traer para su hijo-monje, unas legumbres para comer ${ }^{27}$. Después de la conversión por Gregorio de su casa paterna en un monasterio, Silvia se retiró y vivía solitaria en una pequeña residencia cerca de la iglesia de S. Sabas, donde luego se fundó un oratorio a su memoria $^{28}$. A pesar de la falta de datos fiables sobre esta santa, dada la veneración eclesiástica que la distingue, se puede suponer, que su madre fue para el Santo un ejemplo de santidad.

2. Otras santas parientes: Emiliana, Tarsilia y un mal ejemplo: Gordiana. Entre las santas veneradas en la Iglesia, encontramos también dos tías paternas de S. Gregorio Magno: Emiliana recordada el día 5 de enero ${ }^{29}$ y Tarsilia en el día 24 de diciembre ${ }^{30}$. En la homilía 2, 38, mencionada arriba, el Santo nos da a conocer tres hermanas de su padre, S. Gordiano. Son: Emiliana, Gordiana y Tarsilia. Dice sobre ellas lo siguiente:

„Tres pater meus sorores habuit, quae cunctae tres sacrae virgenes fuerunt: quarum una Tharsilla, alia Gordiana, alia Aemiliana dicebatur. Uno omnes ardore conversae, uno eodemque tempore sacratae, sub districtione regulari degentes, in domo propria socialem vitam ducebant" ${ }^{\prime 31}$.

Las tres, como vemos, unánimemente siguieron la vida virginal. El afán piadoso, que tuvieron sus tías, Gregorio lo describe del siguiente modo:

"Cumque essent diutius in eadem conversatione, coeperunt quotidianis incrementis in amorem conditoris sui Tharsilla et Aemiliana sucrescere, et, cum solo hic essent corpore, quotidie animo ad aeterna transire" ${ }^{32}$.

${ }^{25}$ Cfr. Pablo Diácono, Sancti Gregorii Magni vita 1, PL 75, 41: „Gregorius [...] matre vero Silvia editus”; Juan Diácono, Sancti Gregorii Magni vita I 1, PL 75, 63: „Gregorius [...] beatae Silviae filius".

${ }^{26}$ Más detalladamente sobre las fuentes biográficas vid. J. Czuj, Swięty Grzegorz Wielki, Warszawa 1948, 272-276; R. Godding, op. cit., nn. 2392-2410.

27 Cfr. Juan Diácono, op. cit., I 9, PL 75, 66.

${ }^{28}$ Cfr. ibidem; J.B. Proja, art. cit., col. 1082.

${ }^{29}$ Cfr. Dix mille Saints, p. 167.

${ }^{30}$ Cfr. Dix mille Saints, p. 472.

31 Homiliae II 38, 15, PL 76, 1290-1291.

${ }^{32}$ Ibidem II 38, 15, PL 76, 1291. 
El Santo vió a sus dos tías como a unas santas ya en la vida terrestre. Por eso subraya que el modo de vivir que tenían fue como una vida celestial.

Gregorio atestigua la salvación de ambas. Veamos primero lo que dice sobre Tarsilia, cuya santidad superó a la de sus hermanas: „Quae inter duas alias sorores virtute continuae orationis, gravitate vitae, singularitate abstinentiae ad culmen sanctitatis excreverat" ${ }^{33}$. A esa persona santa se le apareció el famoso antecesor de la familia gregoriana: el papa Félix III $(483-492)^{34}$. De él Tarsilia recibió una información sobre su muerte y obtuvo una visión de la gloria eterna en el cielo. Así al día siguiente se enfermó, tuvo fiebres y murió ${ }^{35}$. Un momento antes de la muerte tuvo una visión de Jesús que se le acercaba ycomo afirma nuestro Autor - su santa alma abandonó el cuerpo en vísperas de Navidad $^{36}$. La presencia del mismo Salvador tiene que confirmar el olor muy agradable que sentían los reunidos ${ }^{37}$.

La otra santa tía de Gregorio: Emiliana, murió pocos días después. Aquí también Gregorio menciona otra aparición celestial, pues se le apareció Tarsilia después de Navidad diciendo: „Veni, ut quia Natalem dominicum sine te feci, sanctum Theophaniae diem jam tecum faciam"38. Así después de esta invitación en las vísperas de la Epifanía dió su alma a Dios. Sin ninguna duda podemos afirmar que las personas de las tías le sirvieron a S. Gregorio como ejemplos ascéticos y morales. Él mismo dice al final de su relato:

„Haec ergo dixi, ne quis in bono jam opere positus sibi vires bono operis tribuat, ne quis de propria actione confidat, quia etsi jam novit hodie qualis sit, adhuc cras quid futurus sit nescit. Nemo ergo de suis jam operibus securus gaudeat, quando adhuc in hujus vitae incertitudine qui finis sequatur ignorat" ${ }^{\prime 39}$.

El papa exhorta a sus oyentes que no se fíen de sus propias fuerzas para obrar el bien, advirtiendo que nadie puede estar seguro hasta fin de sus días.

En la explicación parenética de Gregorio se dan dos caminos: uno positivo y otro negativo. El camino positivo viene representado por los ejemplos de las mujeres mencionadas más arriba. Ante todo encontramos en esas personas una viva afirmación de la vida ascética. Como ya hemos dicho vivían juntas bajo

${ }^{33}$ Dialogi IV 17, 1, SCh 265, 68.

${ }^{34}$ Cfr. J.T. Milik, La famiglia di Felice III Papa, „Epigraphica” 28 (1966) 140-142.

35 La escena de la muerte de Tarsilia tiene analogías en los escritos posteriores de Gregorio, como por ejemplo en los de Jonas de Bobbio; cfr. A. De Vogüé, La mort dans monastères: Jonas de Bobbio et les Dialogues de Grégoire le Grand, en: Mémorial Dom Jean Gribomont (1920-1986) = „Studia Ephemeridis Augustinianum” 27 (1988) 607-608.

${ }^{36}$ Cfr. Dialogi IV 17, 1-3, SCh 265, 68-70; Homiliae II 38, 15, PL 76, 1291-1292.

${ }^{37}$ Cfr. Dialogi IV 17, 2, SCh 265, 68; Homiliae II 38, 15, PL 76, 1291: „tantaque subito fragrantia miri odoris aspersa est, ut ipsa quoque suavitas cunctis ostenderet illic auctorem suavitatis venisse".

${ }^{38}$ Homiliae II 38, 15, PL 76, 1291.

39 Ibidem II 38, 15, PL 76, 1292. 
una severa regla de vida, ofreciéronse a Dios y fervorosamente se esforzaron por la perfección cristiana, viviendo como vírgenes ${ }^{40}$. Al lado de estos rasgos característicos, Gregorio destaca también la necesidad de la oración constante, la austeridad de vida y la abstinencia. Son los valores que llevan a los cristianos a la cumbre de la santidad. Confirman esto los textos mencionados más arriba parcialmente, sobre la conducta de Tarsilia ${ }^{41}$. Así lo atestiguan estas palabras de Gregorio:

„Cumque corpus ejus ex more mortuorum ad lavandum esset nudatum, longo orationis usu in cubitis ejus et genibus, camelorum more, inventa est obdurata cutis excrevisse, et quid vivens ejus spiritus semper egerit, caro mortua testabatur"42.

En consecuencia, queda muy bien expresada la influencia de vida santa hasta en el cuerpo de Tarsilia. La parénesis gregoriana aparece también en un ejemplo negativo: el que ofrece la tercera hermana de padre de Gregorio: Gordiana, que empezó la vida ascética con sus dos hermanas y luego la dejó. En la base de tal ejemplo nuestro Autor afirmará que nadie se puede atribuir a sí mismo la bondad y la seguridad, porque nadie sabe que fin tendrá su vida ${ }^{43}$.

Gordiana era para sus dos piadosas hermanas un problema moral, ya que mientras ellas crecieron en el amor a Dios, ella cada día se alejaba de ese amor, optando por la vida terrenal. Viendo lo que pasaba, Tarsilia y Emiliana querían ayudarla, pero sin grandes éxitos. Gregorio nos informa sobre ese asunto:

„Quam curabant blanda quotidie redargutione corripere, atque a revitate morum ad gravitatem sui habitus reformare. Quae quidem resumebat vultum subito gravitatis inter verba correptionis, sed cum ejusdem correptionis hora transisset, transibat protinus et superducta gravitas honestatis, moxque ad levia verba redibat. Puellarum gaudebat societate laicarum, eique persona valde onerosa erat quaecunque huic mundo dedita non erat" ${ }^{\mathrm{4}}$.

Como se nota especialmente en las últimas palabras del texto citado, Gordiana fue algo depravada, ya que incluso entre las chicas laicas, se relacionaba más con las mundanas. Por fin se unió totalmente a ellas, abandonando su anterior vida ascética.

No tenemos más datos sobre Gordiana que los suministrados por Gregorio. Este subraya que Tarsilia anunció despúes de su muerte a Emiliana, que no se

${ }^{40}$ Cfr. ibidem II 38, 15, PL 76, 1291.

${ }^{41}$ Dialogi IV 17, 1, SCh 265, 68: ,inter duas alias sorores suas virtute continuae orationis, gravitate vitae, singularitate abstinenciae ad culmen sanctitatis excreverat"; Homiliae II 38, 15, PL 76,1291 : ,inter sorores suas virtute continuae orationis, afflictionis studiosae, abstinentiae singularis, gravitate vitae venerabilis in honore et culmine sanctitatis excreverat".

${ }^{42}$ Cfr. ibidem II 38, 15, PL 76, 1291; Dialogi IV 17, 3, SCh 265, 68-70.

${ }^{43}$ Cfr. Homiliae II 38, 15, PL 76, 1292.

${ }^{44}$ Ibidem II 38, 15, PL 76, 1291. 
preocupara por su hermana, porque ella ya pertenece a las mujeres profanas. Gregorio no escatima palabras severas, refiriéndose a ella dice por ejemplo:

„Gordiana autem mox ut solam remansisse se reperit, ejus pravitas excrevit, et quod prius latuit in desiderio cogitationis, hoc post effectu pravae actionis exercuit. Nam oblita dominici timoris, oblita pudoris et reverentiae, oblita consecrationis, conductorem agrorum suorum postmodum maritum duxit. Ecce omnes tres uno prius ardore conversae sunt, sed non in uno eodemque studio permanserunt, quia juxta dominicam vocem, «Multi sunt vocati, pauci vero electi»"45.

La conclusión parece fuerte, sin embargo, llama la atención que nuestro Autor no habla sobre el fin de su tía. Afirma que había dejado el temor de Dios, la vergüenza y el respeto, incluso olvidó la consagración y se casó con el administrador de sus bienes, sin embargo, no dice que fue condenada. El Santo parece terminar así el relato para inspirar la imaginación moral del oyente.

Por otro lado, no se dice nada sobre la edad de Gordiana. Se puede suponer que no fue avanzada en años, porque gustaba de la compañía de las jovenes $\left(\right.$ puellarum societas $^{46}$ ). Como tal, no nos sorprende su inconstancia. Puede ser, que Gregorio, con intención, no mencione nada sobre eso, sino simplemente trae el caso a colación para presentar las dos posibilidades de la conducta cristiana.

\section{STA. ESCOLÁSTICA - LA PRIMACA DEL AMOR}

Gracias a S. Gregorio disponemos de algunos datos de la hermana de S. Benito: Sta. Escolástica ${ }^{47}$. Aunque nuestro Autor dedicó para ella sólo dos capítulos en los diálogos (II 33 y II 34), sin embargo, tenemos una bibliografía sorprendentemente amplia sobre este tema ${ }^{48}$. El relato gregoriano en el Diálogo II 33 habla sobre la visita de la Santa a su hermano, Benito de Nursia. Abstraemos aquí el tema de la existencia real de esa persona, aunque siguiendo el pensamiento de la mayoría de los autores se puede afirmar que „existió, como existió Benito ${ }^{49}$.

Gregorio nos informa sobre Escolástica, diciéndonos que desde su infancia estuvo dedicada a Dios ${ }^{50}$. Concretamente no se puede afirmar si fue una monja

${ }^{45}$ Ibidem II 2, 38, 15, PL 76, 1292.

${ }^{46}$ Cfr. ibidem II 38, 15, PL 76, 1291.

47 S. Gregorio no informa sobre las fechas de su vida; probablemente vivió entre 480 y 543 , cfr. Dix mille Saints, 449.

${ }^{48}$ Cfr. R. Godding, op. cit., nn. 1354-1364, 1461-1462.

49 G.M. Colombas, El milagro de santa Escolástica. Dos lecturas de san Gregorio Magno, Dialogos II, 33 y 34, ,Nova et Vetera” 11 (1981) 30; cfr. A. Cusack, St. Scholastica: Myth or Real Person?, „Downside Review” 92 (1974) 145-159.

50 Dialogi II 33, 2, SCh 260, 230: „Soror namque eius, Scolastica nomine, omnipotenti Domino ab ipso infantiae tempore dicata". 
o si sólo fue una virgen devota que vivió en su casa, como también era costumbre en esos tiempos ${ }^{51}$. El término cella propria que utiliza Gregorio puede significar no sólo „celda” sino también su casa, especialmente si se tiene en cuenta que S. Benito volvió ad monasterium ${ }^{52}$. Esto parece apoyar mejor la versión de casa privada. Como afirma Colombas tampoco el término sanctimonialis femina usado tres veces por Gregorio significa que Escolástica fue una monja. Por último, el citado autor dice: „En suma, como se ve, ni sanctimonialis femina ni cella resultan argumentos apodícticos para concluir que Escolástica formara parte de una comunidad de religiosas, y menos aún que rigiera esta hipotética comunidad como abadesa ${ }^{53}$.

Tenía esta santa mujer la costumbre de visitar a su hermano una vez al año. En ese momento el monje bajaba a un sitio, cerca de la puerta de la propiedad conventual, para hablar con su hermana. Ocurrió que S. Benito bajó con sus discípulos para encontrarse con la santa mujer. No conocemos bien el sitio donde se encontraron ambos. Probablemente sería un lugar no lejos del monasterio, abajo de la montaña casinense, ya que para Benito le bastaba descender no lejos de la puerta del monasterio, como señala nuestro Autor ${ }^{54}$. Gregorio relata que los hermanos el día entero alabaron a Dios y hablaron sobre cosas santas. Cuando ya se acercaba la noche comieron algo. Luego la hermana pidió a Benito que prorrogase el encuentro hasta la mañana. A Benito no le parecía oportuno y afirmó que quería volver al convento. En ese momento Escolástica empezó a rezar y cuando levantó la cabeza surgió tan gran tormenta y aguacero que el monje incluso no pudo ni salir fuera. Así, como quería la santa, pasaron toda la noche en meditación y charla piadosa.

El siguiente diálogo trata de la muerte de la Santa. Tres días después del acontecimiento de arriba, S. Benito percibió como su alma, bajo la forma de una paloma, había penetrado en la extensión del cielo. Luego leemos una corta referencia sobre el cuerpo de Escolástica que fue sepultado en el mismo sepulcro, que el de S. Benito.

Está claro que las narraciones sobre Sta. Escolástica las podemos tomar de dos modos diferentes. En el nivel histórico no hay nada que añadir, y aunque no todos los detalles parecen claros, sin embargo no pertenecen al núcleo de

${ }^{51}$ Como habían hecho por ejemplo las tías de Gregorio, cfr. Homiliae II 38, 15, PL 76, 1290 1291.

${ }_{52}$ Cfr. Dialogi II 34, 1, SCh 260, 234: „Cumque die altero eadem venerabilis femina ad cellam propriam recessisset, vir Dei ad monasterium rediit".

${ }^{53}$ G.M. Colombas, art. cit., p. 32; cfr. A. Linage Conde, En el centenario de santa Escolástica. Lo eterno femenino en la vida de san Benito, „Nova et Vetera” 10 (1980) 195.

54 Cfr. Dialogi II 33, 2; SCh 260, 230: ,,ad quam vir Dei non longe extra ianuam in possessione monasterii descendebat"; cfr. A. Pantoni, Un venerando santuario cassinese: la chiesa di santa Scolastica o del „colloquio”, „Benedictina” 1 (1947) 25-41; idem, Sulla località del convegno annuale di s. Benedetto e s. Scolastica, e sul monasterio de Piumarola, „Benedictina” 15 (1968) 206-228; I. Schuster, Storia di S. Benedetto e dei suoi tempi, Milano 1963, 426. 
nuestro tema. La cuestión más profunda sale a relucir, cuando queremos examinar la profundidad espiritual del texto. Como ya hemos señalado muchas veces, los Diálogos tienen ante todo una dimensión parenética, tienden a edificar los corazones de los lectores ${ }^{55}$. Colombás, por ejemplo, afirma que las páginas gregorianas ,no se redactaron para hacerlas objeto de una lectura crítica, sino de una lectura sapiencial, de una lectio divina propiamente dicha" ${ }^{" 56}$. En este campo podemos distinguir por lo menos tres modos de ver el problema. Primero es la cuestión del mismo encuentro: ¿por qué se encontraron?; ¿qué habían hecho durante los encuentros? etc. La segunda cuestión es la del papel concreto de Escolástica en esta escena; y tercera, la escatológica, que toca al Diálogo 34, es decir la cuestión de la muerte de la Santa y el significado de la visión de su hermano.

Merece la pena subrayar que la intención de los encuentros anuales entre Sta. Escolástica y su hermano es muy significativa espiritualmente. Gregorio no dice que se encontraron para simplemente hablar o alegrarse de sí mismos, sino concretamente afirma: „qui totum diem in Dei laudibus sacrisque conloquiis ducentes" $" 57$. Parece claro, que el motivo basado en el amor familiar, no fue la única causa de los encuentros ${ }^{58}$. Gregorio al hablar de este encuentro, probablemente quiere animar a sus lectores a que primero amen firmemente a su familia y a la vez, que subordinen ese cariño al amor más alto: el amor a Dios, como había hecho esta mujer. De este modo se puede entender que cada encuentro entre los cristianos tiene que ser ante todo una alabanza a Dios. La misma persona de Escolástica parece ser, en la boca de Gregorio, un ejemplo vivo de la mujer cristiana ideal. Destaca el amor a su familia, cocretada en su hermano santo, aunque ese amor debe subordinarse al amor de Dios. El mencionado padre Colombas en la imagen gregoriana de la Santa percibe un reflejo de la esposa del Cantar de los Cantares, y dice, que es como un jardín cerrado para los ojos de los hombres, pero abierto a Dios. Su vida es misteriosa, por eso prácticamente la desconocemos ${ }^{59}$.

El apogeo de la escena del capítulo 33 narra el momento extraordinario de la tormenta. Vemos a la Santa en el instante de hacer su oración. Nuestro Autor parece, otra vez, que desea ofrecer un ejemplo sobre la necesidad de orar y y su eficacia subsiguiente. Escolástica orando llora, su oración es sincera

${ }^{55}$ Cfr. Dialogi Prol., 9, SCh 260, 16: „Fit vero plerumque in audientis animo duplex adiutorium in exemplis patrum, quia et ad amorem venturae vitae ex praecedentium comparatione accenditur, et iam si se esse aliquid aestimat, dum de aliis meliora cognoverit, humiliatur".

56 G.M. Colombás, art. cit, p. 34.

57 Dialogi II 33, 2, SCh 260, 230.

58 El citado padre Colombas conjetura que éste amor a hermano fue tan verdadero y profundo que inclinó a Escolástica a vivir cerca del monasterio de su hermano; cfr. G.M. Colombas, art. cit., p. 34 .

${ }^{59}$ Cfr. G.M. Colombas, art. cit., p. 34. 
y por una vez profunda, marcada por una gran confianza. Es el ejemplo de la verdadera oración. No sorprende, entonces, el fin de esa acción:

„Sanctimonialis quippe femina, caput in manibus declinans, lacrimarum fluvios in mensam fuderat, per quos serenitatem aeris ad pluviam traxit. Nec paulo tardius post orationem inundatio illa secuta est, sed tanta fuit convenintia orationis et inundationis, ut de mensa caput iam cum tonitruo levaret, quatenus unum idemque esset momentum et levare caput et pluviam deponere"

Hay que recordar que en el cielo no se encontraba ni una nube en el momento del inicio de la oración ${ }^{61}$.

S. Gregorio parece narrar el problema de modo directo, aunque algunos científicos quieren ver aquí los elementos de la alegoría, percibiendo en la Santa una personificación de la virtud de la contemplación. Wansbrough, por ejemplo, refiriéndose a la utilización por parte de nuestro Autor de las etimologías, afirma que el nombre de Escolástica equivale al término latino otium (descanso, tranquilidad) yápor eso el nombre puede significar la tendencia a la contemplación ${ }^{62}$. Esta interpretación, basada en el método de Redactionsgeschichte, conduce a interpretar unos hechos muy reales de modo alegórico $^{63}$. Por ejemplo, el hecho de comer significa, en esta dimensión, un refresco espiritual, como un retiro ${ }^{64}$. La conclusión que procede de esa óptica interpretativa es clara: narrando estos hechos, sobre Escolástica, el Santo había manifestado su ideal de vida monástica ${ }^{65}$.

Otro punto de vista es el que representa Laporte ${ }^{66}$. En la pregunta de Benito: „Quid est quod fecisti”, ${ }^{67}$, aprecia su duda frente a la posibilidad de haber usado algún tipo de magia por su mujer. Según su interpretación solamente la respuesta: ,,Rogavi Dominum meum et audivit me "68 desvaneció las dudas de S. Benito. De Vogüé critica, sin embargo, tal posibilidad diciendo que Gregorio podría tener en cuenta las inclinaciones de los oyentes, pero seguramente no podría atribuir acciones mágicas a su hermana. Benito sabe bien que Escolástica recibió estos efectos meteorológicos no por magia, sino por ora-

${ }^{60}$ Dialogi II 33, 3, SCh 260, 232.

${ }^{61}$ Cfr. ibidem II 33, 3, SCh 260, 232: „Tanta vero erat caeli serenitas, ut nulla in aere nubes appareret".

${ }^{62}$ Cfr. J.H. Wasbrough, St. Gregory's Intention in the Stories of St Scholastica and St Benedict, „Revue Bénédictine” 75 (1965) 145-151.

${ }^{63}$ Cfr. ibidem, p. 148.

${ }^{64}$ Cfr. ibidem, p. 147: „When Benedict, therefore, goes to sup with Scholastica, he goes to refresh himself with contemplation, with a day of recollection, as we should say novadays".

${ }^{65}$ Cfr ibidem, p. 151: „We thought he was attempting to write history; we did not realise he was engaged upon the „cura pastoralis" for which he gave up his ideal of monastic life".

${ }^{66}$ Cfr. J. Laporte, Saint Benoît et le paganisme, Saint-Wandrille 1963, 24-26.

${ }^{67}$ Dialogi II 33, 4, SCh 260, 232.

${ }^{68}$ Ibidem. 
ción $^{69}$. La turbación de Benito proviene - según este autor - más de la posible violación de la regla monástica que de la duda.

Por otro lado, el mismo De Vogüé propone otra interpretación, comparando la escena del encuentro entre los santos con la imagen evangélica del otro encuentro entre la pecadora y el fariseo ${ }^{70}$. Desarrollando esa idea saca de las palabras de Gregorio un significado más profundo y las interpreta como una imagen de la relación entre la mujer y el hombre. El hombre tiene aquí el papel del justo y la mujer de alguien culpable ${ }^{71}$. Si tenemos en cuenta la actitud de Gregorio frente al problema, no nos sorprende tal explicación; basta referirse a la frase, donde nuestro Autor compara la mujer con la enfermedad ${ }^{72}$.

Por fin la conclusión del relato gregoriano es interesante y efectivamente parecida a la frase bíblica de Lc 7, 47:

„Nec mirum quod plus illo femina, quae diu fratrem videre cupiebat, in eodem tempore valuit. Quia enim iuxta Iohannis vocem «Deus caritas est», iusto valde iudicio illa plus potuit, quae amplius amavit" ${ }^{33}$.

Esta había recibido más porque más amó: éste es el núcleo de toda la narración gregoriana. Nuestro Autor indica que el amor es como la cumbre de la vida cristiana; es como un camino a Dios, ya que el Señor satisfizo el ruego de Escolástica y aunque también la intención de su hermano a cumplir las normas de la Regla fuera buena, sin embargo, a él no le respondió el Señor, sino a la oración del amor. Siguiendo entonces a De Vogüé podemos afirmar que „Escolástica representa, no tanto, la contemplación como el amor ${ }^{74}$.

Con el cap. 33 está orgánicamente vinculado el siguiente. La entrada al cielo es la consecuencia de una vida santa. La piadosa mujer en forma de una paloma penetra los cielos. El hermano Benito, vencido hace tres días por el amor de su hermana, está muy alegre por la entrada de Escolástica en el cielo. El resultado de eso lo expresan sus himnos y alabanzas dirigidos al Señor. En seguida, envía a sus compañeros para llevar el cuerpo y colocarlo en el sepulcro preparado para sí mismo. „Quo facto contigit - cuenta el Papa - ut quorum

${ }^{69}$ Cfr. A. De Vogüe, La rencontre de Benoît et de Scholastique. Essai d'interprétation, „Revue d'histoire de la spiritualité" 48 (1972) 258-259.

${ }^{70}$ Cfr. Lc 7, 36-50.

71 Cfr. A. De Vogüe, art. cit., p. 265: „De part et d'autre aussi, un homme et une femme sont en présence, voire en opposition: ici Benoît et Scholastique, là le pharisien et la pécheresse. L'homme joue dans les deux cas le rôle du juste, champion de la loi, tandis que la femme apparaît de part et d'autre comme fautive [...]. La recontre de Benoît et de Scholastique est donc une transposition de la scéne du pharisien et de la pécheresse en l'évangile de Luc".

72 Cfr. Moralia in Job XI 49, 65, CCL 143A, 623: „In sacro eloquio mulier aut pro sexu ponitur aut pro infirmitate".

73 Dialogi II 33, 5, SCh 260, 234.

74 A. De Vogüé, art. cit., p. 267: „Scholastique ne représente donc pas la contemplation, mais l'amour". 
mens una semper in Deo fuerat, eorum quoque corpora nec sepultura separaret" ${ }^{75}$. Hay que observar que S. Gregorio, subrayando el amor fraternal o en general el amor cristiano, indica concretamente, que este amor debe tener su base en Dios, así como fue en el caso de Sta. Escolástica y S. Benito (mens una semper in Deo fuerat).

Llama la atención en esa historia el hecho que Escolástica, está presentada como la portadora del amor o como quiere el citado De Vogüé casi como una personificación de éste. No podemos, por supuesto, sacar conclusiones demasiado amplias, afirmando como algunos quieren, que Gregorio exalta de ese modo la feminidad en general ${ }^{76}$. No obstante, no existe nada en contra para constatar que nuestro Autor ve en la persona de la mujer, la de la hermana de S. Benito, un modelo del amor cristiano y de la confianza en Dios frente al hombre, su hermano, atado por la literalidad de la regla monacal. Concluyendo se puede confirmar que el centro del mensaje gregoriano contenido en los fragmentos examinados está en la primacía del amor que está representada por la mujer.

\section{STA. FELICIDAD Y STA. INS - LA GLORIA DEL MARTIRIO}

Entre las homilías gregorianas encontramos tres pronunciadas en los días en que se commemoraban unas santas mártires. Son: la homilía 1, 3 „habita ad populum in basilica sanctae Felicitatis martyris, in die natalis ejus" "77 y también las 1, 11 y 1, 13 con la anotación: ,habita ad populum in basilica sanctae Agnetis, in die natalis ejus" ${ }^{, 78}$. Aunque los dos últimos discursos fueron pronunciados con ocasión de la memoria litúrgica de Sta. Inés y en la basilica de su nombre, sin embargo, sólo el 1, 11 tiene como tema la persona de la Santa y además solamente en un fragmento. Mucho más desarollada es la descripción de la persona de Sta. Felicidad que tiene una homilía corta pero en totalidad dedicada a su persona.

1. Sta. Felicidad ${ }^{79}$. Entre las fuentes que utiliza S. Gregorio figura la Passio de Sta. Felicidad según apunta: „,sicut in gestis ejus emendatioribus legitur..."

${ }^{75}$ Dialogi II 34, 2, SCh 260, 234.

${ }^{76}$ Cfr. A. Linage Conde, art. cit., p. 197: ,Y es que para él todo el episodio protagonizado por Escolástica es femenino por autonomasia, está hechido de feminidad”.

77 Homiliae I 3, título, PL 76, 1086.

78 Ibidem I 11, título, PL 76, 1114; I 12, título, PL 76, 1118. Por dies natalis entendemos el día de la muerte (nacimiento a la vida eterna), cfr. Diccionario ilustrado latino-español, español-latino, Barcelona 1964, 316. Otra palabra correspondiente es natalitia, la cual S. Gregorio usa en lugar del término citado, cfr. Homiliae I 3, 3, PL 76, 1087; I 11, 3, PL 76, 1115.

${ }^{79}$ Santa fue martirizada con sus siete hijos bajo el gobierno de Marco Aurelio (161-180), probablemente en el año 165, cfr. F. Caraffa, Felicità, BS V 605-608.

${ }^{80}$ Homiliae I 3, 3, PL 76, 1087. 
Parece indudable que Gregorio había leído algunos documentos sobre la santa, sin embargo, no está seguro cuales. El más antiguo documento que recuerda a nuestra Santa es Martyrologium Hieronymianum (V s.). Este y los Sacramentarios romanos la veneran el día 23 de noviembre. Saxer subraya que el relato sobre Sta. Felicidad y sus siete hijos mártires tiene rasgos legendarios y puede ser una copia romana del episodio bíblico de la madre de los siete macabeos. Además los itinerarios posteriores consideran como hijo suyo al martir Silano, del grupo del 10 de junio. Estos por su parte se refieren a una Passio legendaria y convierten a Felicidad en la madre de los siete mártires ${ }^{81}$. Es posible que el texto leído por nuestro Autor fuera el mismo que Ruiz Bueno publica en su obra $^{82}$.

Nuestro Autor explica al principio de la homilía su asombro frente al texto bíblico, en que Jesucristo afirma que cada uno que cumple la voluntad del Padre celestial es su hermano, su hermana y su madre ${ }^{83}$. Por eso dice:

„Sed cum is qui voluntatem Patris fecerit soror et frater Domini dicitur, propter utrumque sexum qui ad fidem colligitur mirum non est; mirandum vero valde est quomodo etiam mater dicatur [...]. Qui ergo frater Domini fieri ad fidem veniendo potuerit, quaerendum est quomodo etiam et mater esse possit" ${ }^{\prime 84}$.

La admiración de Gregorio no dura mucho tiempo, en seguida responde a su duda diciendo que ,sciendum nobis est quia qui Christi frater et soror est credendo, mater efficitur praedicando" ${ }^{\circ 5}$. Se puede, por tanto, apreciar que alguien se hace su madre, cuando por medio de su voz en su alma nace el amor del Señor. El vivo ejemplo de tal acción es a los ojos de Gregorio, Sta. Felicidad. Esta se había convertido por su fe en sierva de Cristo y por mostrar a Cristo a los hijos se había hecho la madre de $\mathrm{El}^{86}$.

En los siguientes puntos de la narración el Papa va a analizar la actitud de la Mártir y a presentarla desde la perspectiva de la cura pastoralis. Se puede distinguir unos cuantos aspectos de la figura de la santa. En primer lugar la presenta como el modelo de la madre cristiana. En segundo lugar como un ejemplo de martirio. Un tercer aspecto es presentarla como un retrato de la lucha espiritual. Por último nuestro Autor consideró oportuno dedicar algunas palabras a la mujer en general. En primer lugar como madre de siete hijos, no sólo en el aspecto corporal, sino también en sentido espiritual. Es, como hemos señalado arriba, la madre de Cristo en sus hijos:

${ }^{81}$ Cfr. V. Saxer, Felicidad, DPAC I 866-867.

82 Cfr. D. Ruiz Bueno, Actas de los mártires, Madrid 1951, 288-298.

${ }^{83}$ Cfr. Mt 12, 50.

${ }^{84}$ Homiliae I 3, 2, PL 76, 1086.

${ }^{85}$ Ibidem.

${ }^{86}$ Cfr ibidem I 3, 3, PL 76, 1087: „,credendo extitit ancilla Christi, et praedicando facta est mater Christi." 
„In persecutionis enim labore deprehensa filiorum corda in amore supernae patriae praedicando roboravit, et parturivit spiritu quos carne pepererat, ut praedicatione pareret Deo quos carne pepererat mundo"87.

Como madre cristiana, intentaba fortalecer a sus hijos. Su temor maternal por ellos no está centrado en las preocupaciones terrenales, sino que el objetivo principal que se propone es conseguir para ellos la vida eterna. Su afán es tan vigoroso que „Timuit viventibus, gavisa est morientibus. Optavit nullum post se relinquere, ni si quem haberet superstitem, non posset habere consortem" 88 . La madre verdaderamente cristiana no puede tener otra visión del bien de sus hijos como tenerles cerca de sí misma en el reino eterno, por eso Felicidad teme por los hijos y más: prefiere verlos muertos para Cristo que vivos en este mundo, donde siempre hay posibilidad de caer. Para no juzgar a esa mujer nuestro Autor en seguida justfícala:

„Neque enim filios quos carnem suam esse noverat sine dolore poterat morientes videre, sed erat vis amoris interior quae dolorem vinceret carnis [...]. Amavit ergo juxta carnem Felicitas filios suos, sed pro amore coelestis patriae mori etiam coram se voluit quos amavit" ${ }^{\prime 9}$.

No fue ajeno para ella el amor maternal según el modo humano, sin embargo, en su corazón llameaba el amor supremo inspirado por la gracia divina. Como modelo de madre cristiana merece su elogio y debe inspirar a los corazones de las madres cristianas.

En continuidad con lo dicho anteriormente, hay que considerar la ejemplaridad del martirio de esta mujer. S. Gregorio llega a comparar a Sta. Felicidad con S. Juan Bautista, de quien Cristo dice que es "más que un profeta"90:

„Ad mortem stetit imperterrita. Amittere se in filiis lumen veritatis timuit, si non fuisset orbata. Numquid ergo hanc feminam martyrem dixerim? Sed plus quam martyrem. [...]. Johannes vero plus quam propheta est, quia quem verbo dixit digito ostendit. Non ergo hanc feminam martyrem, sed plus quam martyrem dixerim, quae, septem pignoribus ad regnum praemissis, toties ante se mortua, ad poenas prima venit, sed pervenit octava. Aspexit mater et cruciata et imperterrita filiorum mortem, spei gaudium adhibuit dolori naturae.[...]. Ipsa eorum vulnera accepit, sed ipsa in eisdem ad regnum praevenientibus excrevit. Recte enim hanc feminam ultra martyrem dixerim, quae toties in filiis desiderabiliter exstincta, dum multiplex martyrium obtinuit, ipsam quoque martyrii palmam vicit [...]. Vicit ergo beata Felicitas martyres, quae, tot ante se morientibus filiis, pro Christo frequenter occubuit, quia et amori illius sola sua mors minime suffecit"

\footnotetext{
${ }^{87}$ Ibidem.

88 Ibidem.

89 Ibidem I 3, 3, PL 76, 1087-1088.

90 Mt 11, 9.

91 Homiliae I 3, 3, PL 76, 1087-1088.
} 
El ejemplo del martirio que había dejado Felicidad a los descendientes es muy notable. La Santa no es cualquier mártir: ella supera a los otros mártires que han muerto antes. En la muerte, pues, de los siete hijos, ella sufre la muerte repetida siete veces. Leyendo el texto gregoriano automáticamente brota una gran admiración por su comportamiento.

Hay que tener en cuenta que la intención de Gregorio no fue sólo presentar un ejemplo de maternidad cristiana o de martirio. El objeto de sus palabras parece ser más amplio. El martirio vinculado con las persecuciones en los finales del siglo VI, cuando predicaba S. Gregorio ${ }^{92}$, prácticamente ya pertenecía a la historia. Sin embargo, bajo el término martyrium podemos descubrir una realidad mucho más cercana a nosotros. Pues nuestro Autor considera también otro tipo de martirio y lo explíca al diácono Pedro del modo siguiente:

„Duo sunt, Petre, martyrii genera: unum in occulto, alterum quoque in publico.

Nam et si persecutio desit exterius, martyrii meritum in occulto est, cum virtus ad passionem prompta flagrat in animo. Quia enim esse possit et sine aperta passione martyrium, testatur in Evangelio Dominus" ${ }^{93}$.

El nuestro interior no es sólo la disposición a ser mártir, si se presentara la ocasión. El sentido es más amplio y prácticamente toca a la vida cotidiana. Así lo afirman las palabras de S. Gregorio:
„Nam quamvis occasio persecutionis desit, habet tamen et pax nostra martyrium suum, quia etsi carnis colla ferro non subdimus, spiritali tamen gladio carnalia desideria in mente trucidamus, ipso adjuvante" ${ }^{\prime 94}$.

En el fundamento del martirio de Sta. Felicidad el Papa anima a los oyentes al esfuerzo espiritual. El martirio, pues, no necesita significar la muerte sino la coherencia de la vida cristiana ${ }^{95}$. La Santa aparece entonces como guía que nos conduce por medio de su ejemplo a vencer el mal y convertirnos en mártires espirituales de Cristo.

En esta misma Homilía encontramos también estas palabras: „Considerate, fratres charissimi, in femineo corpore virile pectus" "96. Aunque Felicidad era mujer, pero su virtud le parecía masculina a nuestro Santo, algo así como si la

92 Sus Homiliae in Evangelia fueron predicadas en los dos primeros años de su pontificado, cfr. V. Recchia, Gregorio I Magno, DPAC I 992.

${ }^{3}$ Dialogi III 26, 7-8, SCh 260, 370.

94 Homiliae I 3, 4, PL 76, 1089.

95 Este sentido del término martyrium fue conocido ya desde la antigüedad cristiana. Utilízanle muchos autores tanto del Oriente como del Occidente; el estudio más concreto se puede ver en: A.C. Rusch, Spiritual Martyrdom in St. Gregory the Great, ThS 23 (1962) 569-589; A. De Vogüé, „, Martyrium in occulto”. Le martyre du temps de paix chez Grégoire le Grand, Isidore de Séville et Valerius du Bierzo, en: Fructus centesimus. Mélanges offerts à Gerard J.M. Bartenlink à l'occasion de son soixante-cinquième anniversaire, Steenbrugge 1989, 125-140.

96 Homiliae I 3, 3, PL 76, 1087. 
mujer, siendo mujer, no pudiera ser fuerte ${ }^{97}$. Animando luego a los oyentes con el ejemplo de la santa:

„Consideremus, fratres, hanc feminam, consideremus nos, qui in membris corporis viri sumus, in ejus comparatione quid existimabimur" ${ }^{98}$.

Un poco más adelante la actuación de la mártir le sirve para interpelar a los varones que le escuchan:

„Cum ergo ad illud terribile examen districtus judex venerit, quid nos viri dicemus, cum hujus feminae gloriam viderimus? De debilitate mentis suae quae tunc erit viris excusatio, quando haec ostendetur, quae cum saeculo et sexum vicit? Sequamur ergo, fratres charissimi, districtam et asperam Redemptoris viam; usu quippe virtutum ita jam plana facta est, ut per eam feminis libeat ambulare" $"$.

En este fragmento especialmente llama la atención la referencia de que la Santa había vencido con su acción al propio sexo. Ese enfoque supone claramente que el sexo femenino está considerado por nuestro Autor si no directamente como inferior al masculino, por lo menos, más débil. Además, la última frase del citado pasaje, una vez más confirma lo dicho anteriormente: que el camino del seguimiento del Señor es para Gregorio tan llano que incluso las mujeres pueden transitar por él.

2. Sta. Inés. Otra santa mártir, Inés ${ }^{100}$, merece también la atención de Gregorio. Le dedica un breve fragmento en sus homilías, que ofrece una cierta similitud con el analizado anteriormente. Ante todo debemos apuntar el aspecto parenético-pastoral, que sobresale naturalmente en la mayoría de los textos de nuestro Santo. Santa Inés será, por tanto, un ejemplo de martirio y de lucha espiritual.

Ya en la primera frase el Papa afirma la coherencia de la vida cristiana para poder afrontar el martirio:

„Nec enim sancta haec, cujus hodie natalitia celebramus, mori pro Deo potuisset in corpore, si prius a terrenis desideriis mortua non fuisset in mente"101.

La receta para ser mártir es inequívoca: hay que morir en el alma a los deseos terrenales. Esta es la condición sin la cual no se puede llegar al verda-

${ }^{97}$ Consecuencia de la visión de la mujer como ser más débil que el varón.

98 Homiliae I 3, 4, PL 76, 1088.

99 Ibidem.

${ }^{100}$ Santa Inés, virgen, fue martirizada en Roma, en el s. IV. La Santa fue muy popular; su culto se desarrolló ya desde el mismo siglo IV. Sobre esta santa se puede ver en: Franchi De'Cavalieri, Agnese nella tradizione e nella leggenda, RQ Supl, 10, Roma 1899; E. Josi, Agnese, BS I 382-407; V. Saxer, Inés, DPAC I 1090-1091.

101 Homiliae I 11, 3, PL 76, 1115. 
dero martirio cristiano. Los frutos de tal esfuerzo S. Gregorio los muestra diciendo:

„Erectus namque in virtutis culmine animus tormenta despexit, praemia calcavit. Ante armatos reges et praesides ducta stetit, feriente robustior, judicante sublimior" $" 102$.

El cumplimiento de la mencionada condición permitió obtener una inpensada fuerza: su alma elevada a la cumbre del coraje ha desdeñado los tormentos y ha despreciado los premios ofrecidos por apostasía. Se mostró más noble que su juez, más fuerte que su verdugo. Tal fuerza, tal ánimo lo podría obtener sólo por gracia divina.

El ejemplo de Sta. Inés le sirve a Gregorio para estimular a los varones a superar defectos y pecados:

„Quid inter haec nos barbati et debiles dicimus, qui ire ad regna coelestia puellas per ferrum videmus, quos ira superat, superbia inflat, ambitio perturbat, luxuria inquinat" $" 103$.

Vemos otra vez un catálogo de los pecados cometidos por los hombres. Como en el caso de Felicidad, también en Inés percibimos la figura de alguien, que había vencido todo eso. Además siendo una joven. Apoyándose en su ejemplo Gregorio lo aprovecha para animar al „martirio espiritual”:

„Ecce nulli nostrum hoc tempore dicit Deus: Pro me morere, sed: Illicita tantummodo in te desideria occide" ${ }^{104}$.

Dios, resume nuestro Autor, no espera en el tiempo de la paz el sacrificio de nuestra vida, sino en su amor quiere que matemos en nuestro corazón eso que no es bueno, los deseos ilícitos; basándose en el amor de Cristo. Rush, refiriéndose a los ejemplos presentados por Gregorio, incluso dirá que „el amor de Cristo es el motivo predominante en el martirio espiritual ${ }^{105}$.

\section{LOS EJEMPLOS MENOS DESTACADOS}

El grupo de santas que hemos enumerado no constituye la totalidad de todas las santas mencionadas por S. Gregorio. A un lado queda otro grupo bastante numeroso de menor cuantía. Sin embargo, no se debe privar totalmente de importancia a esas mujeres. Hablando más concretamente dispone-

${ }^{102}$ Ibidem, I 11, 3, PL 76, 1115-1116.

103 Ibidem, I 11, 3, PL 76, 1116.

104 Ibidem.

105 A.C. Rusch, art. cit., p. 578: „Love for Christ is the predominant motive in spiritual martyrdom". 
mos de dos capítulos de los Diálogos y también dos párrafos en la homilía sobre el texto evangélico de Lc 16, 19-31.

1. Gala. En la corriente de las narraciones piadosas nuestro Autor menciona la escena de la muerte de Gala ${ }^{106}$. Según narra en el Diálogo, fue la hija de Simmaco, cónsul y patricio. Contrajo matrimonio de joven y enviudó despúes de un año. San Gregorio explica como prefirió vivir:

„Quam dum, feruente mundi copia, ad iterandum thalamum et opes et aetas vocaret, elegit magis spiritalibus nuptiis copulari Deo, in quibus a luctu incipitur, sed ad gaudia aeterna pervenitur, quam carnalibus nuptiis subici, quae a laeticia semper incipiunt et ad finem cum luctu tendunt"107.

Merece la pena subrayar el término usado nuptiae spiritalis. Encontramos aquí una cierta analogía con el problema del martirio espiritual mencionado en el apartado anterior, sobre todo, si tenemos en cuenta que la viudez entendida como „nupcias espirituales” se asimila a la virginidad vivida por motivos espirituales.

Gala, pues, eligiendo la vida de las „nupcias espirituales” con el Señor y renunciando al matrimonio con algún candidato, se expuso al peligro de algunas complicaciones médicas. Leemos:

„Huic autem cum valde ignea consparsio corporis inesset, coeperunt medici dicere quia, nisi ad amplexus viriles rediret, calore nimio contra naturam barbas esset habitura; quod ita quoque post factum est" ${ }^{\prime 108}$.

No sorprenden aquí las explicaciones de los médicos de la época, ni la veracidad de Gregorio sobre el crecimiento de la barba a la mujer que se negó al matrimonio. Probablemente en esta leyenda tenemos un reflejo de las narraciones del pueblo que tenían como objeto inclinar al matrimonio a esas casaderas que no lo querían contraer, pero no entraremos en este asunto. Para nosotros es importante que Gala no capituló incluso conociendo la posibilidad de esas problemas. El Papa en seguida explica:

„sancta mulier nil exterius deformitatis timuit, quae interioris sponsi speciem amavit, nec verita est si hoc in illa foedaretur, quod a caelesti sponso in ea non amaretur" ${ }^{\prime 109}$.

Gala aparece en esa narración como un ejemplo de actuar según la prudencia. Ella sabe distinguir entre la belleza externa e interna. Por eso no se

\footnotetext{
106 Cfr. Dix mille Saints, p. 212.

107 Dialogi IV 14, 1, SCh 265, 54-56.

108 Ibidem, IV 14, 2, SCh 265, 56.

109 Ibidem.
} 
asustó: Gala sabía bien que la belleza terrenal no será el objeto del amor de su Esposo espiritual en el cielo.

Como consecuencia de esa decisión fue la entrada de la mujer en el claustro en un monasterio existente cerca de la Iglesia de S. Pedro. Gregorio destaca algunos aspectos de su vida conventual, como son: la simplicidad del corazón, la oración y la limosna ${ }^{110}$. A todos los puntos mencionados es necesario añadir también, el odio a todo mal, presentado por Gregorio bajo forma alegórica, como el rechazo a la oscuridad:

„Nocturno autem tempore ante lectum illius duo candelabra lucere consueverant, quia videlicet amica lucis non solum spiritales, sed etiam corporales tenebras odio habebat"111.

Generalmente la oscuridad siempre ha significado algo malo, al contrario de la luz, que es sinónimo del bien ${ }^{112}$.

En el texto aparece Gala viviendo en el convento como un ejemplo del amor tanto al Señor como a los hombres. Su amor a Dios lo atestigua bastante la decisión de dedicar su vida a la vida espiritual y retirarse de la vida terrenal. Todo eso además está ampliado por la simplicidad y la oración. Este amor ejemplar no impide practicar el amor al prójimo que por otro lado se concreta en la limosna. En pocas líneas nuestro Autor nos da la imagen del prototipo de la verdadera vida cristiana: la vida monacal, tan favorecida por el Papa Gregorio y el amor. Gala aún siendo mujer, puede servirle como tipo del ideal de vida cristiana tanto para mujeres, como para los hombres.

Para corrobar, que el mencionado estilo de vida vale la pena y da frutos, el Papa describe la escena final de la vida de Gala:

„Cumque omnipotens Deus perennem iam mercedem reddere eius laboribus decrevisset, cancri ulcere in mamilla percussa est" $" 113$.

Lo más importante, en la frase citada, es el hecho, que Dios decidió darle a ella el premio eterno como recompensa de su trabajo. La enfermedad debe entenderse aquí como un medio para que la santa salga de esta vida y alcance la vida futura $^{114}$.

${ }^{110}$ Cfr. ibidem, IV 14, 3, SCh 265, 56: „multis annis simplicitati cordis atque oracioni dedita, larga indigentibus elemosinarum opera inpendit”.

111 Ibidem.

112 Cfr. W. Hackenberg, sktoj, en: H. Balz - G. Schneider (red.), Diccionario exegético del Nuevo Testamento, t. 2, Salamanca 1998, 1440-1442.

113 Dialogi IV 14, 3, SCh 265, 56.

${ }^{114}$ El tema de la muerte es frecuente en la literatura de esa epoca. Gregorio describe muchas escenas de la muerte de los santos, empezando de su tía Tarsila a través de los ejemplos que ahora vamos a analizar. Un estudio más detallado sobre ese problema es posible encontrarlo en los siguientes títulos: P. Boglioni, La scène de la mort dans les prémieres hagiographies latines, en: Le sentiment de la mort au moyen âge. Études présentées au $5^{e}$ Colloque de l'Institut d'Études 
En el Diálogo encontramos también algunos aspectos de la profecía. Gala tres días antes de su muerte, por la noche, tiene un encuentro con el apóstol S. Pedro, que se le apareció entre dos candelabros puestos ante su cama. La visión no la asustó. Por el contrario Gregorio dice que se alegró y sacando fuerzas del amor le preguntó por la visión y por el perdón de sus pecados. Nuestro Autor describe la escena del modo siguiente:

„Quae dum nocte quadam ex hac eadem iaceret infirmitate fatigata, vidit beatum Petrum apostolum inter utraque candelabra ante suum lectulum constitisse. Nec perterrita timuit, sed ex amore sumens audaciam exultavit, eique dixit: «Quid est, domine meus? Dimissa sunt mihi peccata mea»? Cui ille, benignissimi ut est vultus, inclinato capite annuit, dicens: «Dimissa. Veni»"

La santa no tiene miedo frente a un mensajero de la luz, ella, que vivió en la luz. Sin embargo, no vemos en la actitud de Gala una certeza absoluta, porque pregunta a Pedro si sus pecados están ya perdonados y recibe una respuesta positiva. Esto es otro reflejo de las opiniones de Gregorio sobre la vida cristiana. El Papa seguramente quiere subrayar esta realidad: el cristiano debe ser santo aunque nunca tiene la certeza de su santidad; y por otro lado no puede perder la esperanza, porque en su corazón arde el amor de Dios. La confirmación de Pedro permite continuar el coloquio con el apóstol. Recibe información sobre las fechas de la muerte de otras dos monjas. En seguida informó a la priora sobre el acontecimiento. Por supuesto que las informaciones recibidas de S. Pedro se cumplieron totalmente ${ }^{116}$.

2. Herundina, Redenta y Rómula. Un poco más adelante, en los Dialogi, tenemos ocasión de encontrar la mención de tres santas que llevaban vida ascética. Existe también un texto paralelo en la Homilía 2, 40 sobre los Evangelios. Las tres mujeres son veneradas como santas por la Iglesia ${ }^{117}$.

Sobre Herundina el Santo casi no habla. Los únicos datos que tenemos son los siguientes: „Herundinis [...] quae magnis virtutibus pollens super Praenestinos montes vitam heremiticam duxisse ferebatur"118. Gregorio utiliza las mismas palabras hablando de ella en una homilía ${ }^{119}$. Los datos son muy breves: sabemos que alude a sus „grandes virtudes”, pero sin más concreción; lo mismo sucede en la „vida eremítica” y con el lugar geográfico donde vivió.

médiévales de l'Université de Montréal, Montréal 1979, 183-210; A. De Vogüé, La mort dans monastères: Jonas de Bobbio et les Dialogues de Grégoire le Grand, en: Mémorial Dom Jean Gribomont (1920-1986), op. cit., p. 593-619.

${ }_{115}$ Dialogi IV 14, 4, SCh 265, 56-58.

116 Cfr. Dialogi IV 14, 5, SCh 265, 58.

117 Cfr. A. Amore, Romola, Redenta ed Erudine, BS XI 348-349.

118 Dialogi IV 16, 1, SCh 265, 62.

119 Cfr. Homiliae II 40, 11, PL 76, 1310. 
Tampoco tenemos mucho escrito sobre Redenta. Sabemos que fue discípula de la mencionada Herundina. El Papa apunta:

„anus quaedam, Redempta nomine, in sanctimoniali habitu constituta, in urbe hac iuxta beatae Mariae semper virginis ecclesiam manebat. Haec illius Herundinis discípula fuerat" ${ }^{\prime 120}$.

Además sabemos por informaciones del Papa que fue guía espiritual de su discípula, Rómula:

„....coepit eadem Romula adsistentem et trementem Redemptam suorum morum magistram blanda voce consolari" ${ }^{\prime 21}$.

Más tarde, Gregorio utiliza otra vez, el término magistra sua ${ }^{122}$. Estas breves palabras, no obstante su cortedad, dicen mucho. Como sabemos Gregorio algunas veces parece tener en menos a la mujer como alguien débil, alguien a quien el diablo tiene un acceso más fácilmente, etc. En la relación con estas tres mujeres parece contradecir esta opinión afirmando que la mujer puede ser incluso guía, directora espiritual (magistra) en el camino del desarrollo de las virtudes. La visión de la mujer que tiene Gregorio se amplia desde esta perspectiva puesto que puede ser incluso maestra de santas personas.

Rómula, como narra en el diálogo, vivió junto con otra condiscípula y su maestra Redenta. Las tres vivían en el mismo lugar. Merece la pena citar el texto sobre ese hecho:

„Huic autem Redemptae duae in eodem habitu discipulae aderant: una nomine Romula, et altera quae nunc adhuc superest, quam quidem facie scio, sed nomine nescio. Tres itaque haec in uno habitaculo conmanentes, morum quidem divitiis plenam, sed tamen rebus pauperem vitam ducebant. Haec autem quam praefatus sum Romula aliam quam praedixi condiscipulam suam magnis vitae meritis anteibat. Erat quippe patientiae mirae, summae oboedientiae, custos oris sui ad silentium, studiosa valde ad continuae orationis usum"123.

Nuestro Autor, al comienzo del citado pasaje, utiliza un interesante recurso retórico al afirmar, que no recuerda el nombre de la otra. La otra discípula de Redenpta no vale la pena mencionarla porque no aporta ningún ejemplo.

Como en el caso de Gala, encontramos las „bases” de la santidad que tenía Romula. Estos pilares espirituales son: la paciencia enorme (patientia mira), la obediencia extraordinaria (summa oboedientia), el silencio (silentium) y la oración continua (continua oratio). Esta lista puede ser ampliada probable-

${ }^{120}$ Dialogi IV 16, 1, SCh 265, 62; cfr. Homiliae II 40, 11, PL 76, 1310.
${ }^{121}$ Ibidem IV 16, 6, SCh 265, 66; cfr. ibidem II 40, 11, PL 76, 1311.
${ }^{122}$ Ibidem IV 16, 7, SCh 265, 66; cfr. ibidem II 40, 11, PL 76, 1311.
${ }^{123}$ Ibidem IV 16, 2, SCh 265, 62-64; cfr. ibidem II 40, 11, PL 76, 1311. 
mente con la virtud de la pobreza, mencionada en el fragmento anteriormente analizado. No nos sorprende entonces el fin de su vida, tan parecido al ya citado caso de Sta. Gala. Rómula cayó enferma. En contraste con el caso de Sta. Gala, la enfermedad de Rómula tiene rasgos ascéticos, es decir, se convierte en un medio más para perfeccionar su alma:

„Sed quia plerumque hii, quos iam perfectos homines aestimant, adhuc in oculis summi opificis aliquid inperfectionis habent - sicut saepe inperiti homines necdum perfecte sculpta sigilla conspicimus et iam quasi perfecta laudamus, quae tamen adhuc artifex considerat et limat, laudari iam audit et tamen ea tundere meliorando non desinit - haec quam praediximus Romula ea, quam graeco vocabulo medici paralysin vocant, molestia corporis percussa est, multique annis in lectulo decubans paene omni iacebat membrorum officio destituta. Nam ipsa ei detrimenta membrorum facta fuerant incrementavirtutum, quia tanto sollicitius ad usum orationis excreverat, quanto et aliud quodlibet agere nequaquam valebat"124.

La argumentación gregoriana en este punto parece mucho más rica. El hombre no es capaz de entender las ideas divinas; es como un imperfecto espectador, que mira a la escultura, pensando que es buena; sin embargo el escultor no la toma por buena, porque conoce sus imperfecciones e intenta mejorarla. Así pasa si estamos viendo una persona buena y pensamos que es santa; pero el Creador, como un artista, conoce sus defectos y quiere borrarlos. Esto hace, algunas veces, por medio de la enfermedad. Como ya hemos mencionado, el sufrimiento de Rómula tiene mucha más profundidad que el de Gala. Aquella sufría el tumor, pero nuestro Autor no destaca tanto su significado ascético como aquí. El sufrimiento de Rómula sirve precisamente, para perfeccionar su persona. Esta mujer da aquí un ejemplo de gran firmeza, ya que el sufrimiento no frena su oración, al contrario, la anima para orar más; no pierde su paciencia, sino que le sirve para crecer en las virtudes.

La escena de su muerte es también misteriosa. Una vez, por la noche, llamó a su maestra, Redenta. Ésta acude con otra discípula, vió una luz gloriosa y oyó la voz de una gran muchedumbre. Al mismo tiempo se podía sentir un olor muy agradable. No veían nada, porque a causa de la luz y el temor bajaron los ojos. En la narración del Papa podemos también descubrir una alusión profética, al decirle Rómula a su maestra, que no va a morir en ese momento. Solamente tres días después la enferma pidió el viático y lo recibió, y en el momento de recibir el viático aparecieron dos coros cerca de su celda y mientras cantaban, murió la Santa. Las canciones de esos coros la acompañaban al cielo y luego desapareció el olor que en esos días acompañaba a Rómula ${ }^{125}$. Hay que hacer notar la composición mixta del coro:

${ }^{124}$ Dialogi IV 16, 3, SCh 265, 64; cfr. Homiliae II 40, 11, PL 76, 1310-1311.

125 Cfr. Dialogi IV 16, 4-7, SCh 265, 64-68; Homiliae II 40, 11, PL 76, 1311-1312. 
„Necdum vero eadem Redempta vel alia eius discipula a lectulo iacentis abscesserant, et ecce subito in platea ante eiusdem cellulae ostium duo chori psallentium constiterunt, et sicut se dicebant sexus ex vocibus discrevisse, psalmodiae cantus dicebant viri et feminae respondebant" ${ }^{\text {126 }}$.

La composición de dos coros con voces femeninas y masculinas confirma la opinión, según la cual, en el camino hacia la santidad no menta el sexo: la entrada al cielo está abierta para todos.

No se debe olvidar tampoco en el caso de Rómula, la dimensión parenética que es típica de nuestro Autor. El texto de la homilía hace mayor hincapíe en estas aplicaciones parenéticas que en el Diálogo:

„Haec ergo quandiu vixit in corpore, quis illam haberet in honore? Indigna cunctis, despecta omnibus videbatur. Quis ad illam accedere, quis illam videre dignaretur? Sed latebat in sterquilinio margarita Dei. Sterquilinium, fratres, hanc ipsam corruptibilitatem corporis appello, sterquilinium abjectionem paupertatis nomino. Assumpta est ergo margarita quae jacebat in sterquilinio, et posita in coelestis Regis ornamento, jam inter supernos cives emicat, jam inter ignitos illos lapides aeterni diadematis coruscat. O vos qui in hoc mundo divites aut esse creditis, aut estis, conferte, si potestis, falsas divitias vestras veris divitiis Romulae. Vos in hujus mundi via omnia amissuri possidetis; illa nihil quaesivit in itinere, et omnia invenit in perventione. Vos laetam vitam ducitis, tristem mortem timetis; illa tristem vitam pertulit, ad laetam mortem pervenit. Vos ad tempus quaeritis obsequium hominum, illa despecta ab hominibus invenit socios choros angelorum. Discite ergo, fratres" ${ }^{\text {127 }}$.

Al lector, seguramente, le sorprenderán las palabras fuertes, donde Gregorio dice que Rómula fue como una perla en el estercolero (sterquilinium), donde por estiércol entendemos, por un lado el cuerpo humano y por otro el rechazo de la pobreza. Rómula, en la boca de Gregorio, parece brillar como una perla preciosa. En esta dirección va la explicación del Papa: la mujer fue despreciada y olvidada por otros, pero gracias a la gracia divina salió de este estercolero. Esta mujer ha vencido el mal y es un ejemplo para otros: los que se consideran ricos, pueden ver en ella un ejemplo de verdadera riqueza; los que viven alegres, pueden descubrir en ella la verdadera alegría; a los que les gusta ser servidos tienen posibilidad de seguir un ejemplo de humildad.

\section{LOS EJEMPLOS LEGENDARIOS}

Al lado de las santas veneradas por la Iglesia y apuntadas oficialmente en el Martyrologium Romanum, nuestro Santo, especialmente en los Diálogos,

${ }^{126}$ Dialogi IV 16, 7, SCh 265, 66; cfr. Homiliae II 40, 11, PL 76, 1311. Esta escena tenía repercusiones en la literatura posterior; cfr. A. De Vogüé, La mort dans monastères: Jonas de Bobbio et les Dialogues de Grégoire le Grand, en: Mémorial Dom Jean Gribomont, op. cit., p. 606.

127 Homiliae II 40, 12, PL 76, 1312. 
cuenta con otros modelos femeninos que podemos clasificar como legendarios. Son diversas imágenes, algunas veces más ricas en su contenido, otras menos interesantes; pero en el conjunto forman una interesante imagen de los diferentes rasgos característicos y de los diferentes valores cristianos. Veamos algunas de ellas.

1. Musa. Analizando los textos sobre la Madre de Dios podemos encontrar una niña nombrada Musa ${ }^{128}$. Es la protagonista del diálogo 4, 18 y hermana de un santo obispo llamado Probus ${ }^{129}$. Además es la única persona femenina de categoría analizada, la que conocemos por nombre. Del contexto se puede deducir que fue una chica de pocos años. Una vez se le apareció la Virgen, presentando algunas niñas vestidas de blanco. Musa deseó pertenecer a su compañía y servir a María. La Virgen escuchó la explicación clara de su deseo y le indicó el camino preciso para entrar aáese maravilloso círculo. Según S. Gregorio fueron los siguientes:

,ut nil ultra leve et puellare ageret, a risu et iocis abstineret, sciens per omnia quod inter easdem virgines, quas viderat, ad eius obsequium die trigesimo veniret"130.

Llaman la atención las palabras en las cuales María prohibe hacer algo infantil (ut nil ultra leve et puellare ageret). Parece que el Santo opina que no realice niñadas o cosas infantiles en general. La lista de los preceptos se completa en la misma línea: la necesidad de abstenerse de las risas y bromas.

Como en los casos de Gala y Rómula, otra vez encontramos una señal profética: la muchacha se entera de la fecha de su muerte. Como no podía ser de otra manera este hecho produjo un cambio fuerte: „Quibus visis - afirma sobre eso el Santo - in cunctis suis moribus puella mutata est, omnemque a se levitatem puellaris vitae magna gravitatis detersit manu"131. El cambio en su conducta sorprendió incluso a los padres de la niña. A la pregunta respondió describiendo el encuentro con la Madre de Dios y reveló la fecha de ir al servicio de la Virgen. Todo sucedió como había anunciado: se enfermó y murió en el trigesimo día cuando vino María para sacarla de este mundo. Nuestro Autor concluye la escena diciendo:

„Die autem trigesimo, cum hora eius exitus adpropinquasset, eandem beatam genitricem Dei cum puellis, quas per visionem viderat, ad se venire conspexit. Cui se etiam vocanti respondere coepit, et depressis reverenter oculis aperta voce clamare: «Ecce, domina, venio. Ecce, domina, venio». In qua etiam voce spiritum reddidit, et ex virgineo corpore habitatura cum sanctis virginibus exivit" ${ }^{\text {"132 }}$.

\footnotetext{
${ }^{128}$ Sobre María vamos hablar en otro artículo, dedicado a las santas bíblicas.

${ }^{129}$ Cfr. Dialogi IV 13, SCh 265, 52-54.

${ }^{130}$ Ibidem IV 18, 1, SCh 265, 70.

${ }^{131}$ Ibidem IV 18, 2, SCh 265, 70.

${ }^{132}$ Ibidem IV 18, 3, SCh 265, 70-72.
} 
En este pasaje merece la pena destacar la humildad, con que Musa se acerca a la compañía celestial.

Como sabemos bien, los Diálogos no proporcionan datos fiables desde el punto de vista histórico, „más bien forman una colección de leyendas, en las cuales encontró su explicación la fantasía de los hombres vivientes en el sitio y tiempo definido; de las cuales luego las generaciones siguientes sacaban las tramas para ulteriores obras de ese tipo ${ }^{133}$. El relato de Musa parece que es más propio de este tipo de narración ${ }^{134}$. Pero esto no significa que no tiene sus valores parenéticos. Por eso al leer los Diálogos hay que tener siempre en cuenta su sentido supra-histórico ${ }^{135}$.

\section{Las imágenes femeninas anónimas.}

2.1. La madre de un muerto. S. Gregorio, hablando sobre un piadoso monje llamado Libertino, menciona también un acontecimiento que le sucedió viajando a Ravena. Encontró a una mujer que llevaba el cuerpo de su hijo muerto. Ella decidió no permitir al monje continuar su viaje si no resucitara al chico. Leemos en el pasaje correspondiente:

„Itaque dum pergeret, accidit ut quaedam mulier extincti filii corpusculum ferret. Quae dum servum Dei esset intuita, amore filii succensa iumentum eius per frenum tenuit atque cum iuramento dixit: «Nullatenus recedis, nisi filium meum suscitaveris»"136.

Animado por la actitud de la mujer, puso en el cadáver un zapato de su antiguo abad Honorato ${ }^{137}$ y el chico resucitó. La razón de este milagro, Gregorio lo descubre en la fe de la mujer y en el poder de los dos santos monjes:

„In ostensione tam admirabilis signi cum fide feminae virtus convenit utrorumque, atque ideo Libertinum existimo ista potuisse" ${ }^{\text {"138. }}$.

La madre del chico a primera vista no parece tener un papel significativo en el texto, sino más bien Libertino. No obstante, analizando su actitud descrita en $\tan$ cortas frases, encontramos algunos rasgos de las tres virtudes cardinales. El

133 J.S. Bojarski, Stowo wstępne, en: Św. Grzegorz Wielki, Dialogi, PSP 2, 12: „Są one raczej zbiorem legend, w których znalazła wyraz fantazja ludzi żyjących w określonym miejscu i czasie, a z których następne pokolenia czerpały wątki do dalszej twórczości tego typu".

${ }^{134}$ La narración sobre Musa probablemente también sirvió de fuente para otras narraciones posteriores; cfr. A. De Vogüé, La mort dans monastères: Jonas de Bobbio et les Dialogues de Grégoire le Grand, en: Mémorial Dom Jean Gribomont. op. cit., p. 603-604.

135 Cfr. W.F. Bolton, The supra-historical Sense in the Dialogues of Gregory I, „Aevum” 33 (1959) 206-213.

${ }^{136}$ Dialogi I 2, 5, SCh 260, 28.

137 Honorat de Fondi, venerado como santo por la Iglesia; cfr. Dialogi I 1, SCh 260, 18-22; Dix mille Saints, p. 251.

${ }^{138}$ Dialogi I 2, 7, SCh 260, 28-30. 
mismo Gregorio habla sobre la fe que unida con la protección de Libertino y S. Honorato, alcanzó la gracia divina de resucitar al chico. Por otro lado, notamos un evidente ejemplo de la esperanza; sin esperanza seguro que no hubiera molestado al monje viajero, para que resucitara a su hijo. Por último en el primero de los dos pasajes citados arriba se menciona al amor, ya que la „mujer estaba ardiendo por amor a su hijo".

2.2. Una mujer y su marido resucitado. Se puede mencionar, en este lugar también, a una pobre viuda, que llorando al lado del cuerpo de su marido muerto, había provocado la compasión en el corazón de un santo monje del monte Argentaria. Este tenía costumbre de visitar una vez al año la Iglesia de S. Pedro, en un lugar llamado Buxentum ${ }^{139}$. y a un subdiácono, llamado Cuadragésimo, que luego fue quien informó a Gregorio. Cerca de la vivienda del diácono murió un hombre. La viuda lloraba cerca de ataúd y ese llanto movió el corazón del monje. El Papa Gregorio relata este suceso:

„Iuxta defuncti igitur corpus viduata mulier sedit, quae in magnis fletibus noctem ducens, continuis lamentorum vocibus satisfaciebat dolori. Cumque hoc diutius fieret et flere mulier nullo modo cessaret, vir Dei, qui receptus hospitio fuerat, Quadragesimo subdiacono conpunctus ait: «Dolori huius mulieris anima mea conpatitur. Rogo, surge et oremus». Perrexerunt igitur utrique ad vicinam ecclesiam, seseque pariter in orationem dederunt. Cumque diutius orassent, conplere orationem Quadragesimum subdiaconum servus Dei petiit. Qua conpleta, ab altaris crepidine pulverem collegit, atque cum eodem Quadragesimo ad defuncti corpus accesit, seseque ibidem in orationem dedit. Cumque diutius orasset, iam non, sicut prius fecerat, conpleri orationem per subdiaconum voluit, sed ipse benedictionem dedit statimque surrexit, et quia dextera manu collectum pulverem gestabat, sinistra palium quo facies defuncti velabatur abstulit. Quod cum mulier fieri cerneret, contradicere vehementer coepit et mirari quid vellet facere. Ablato itaque palio, diu eo quem collegerat pulvere defuncti faciem fricavit. Qui dum diutius fricaretur, recepit animam, oscitavit, oculos aperuit, seseque elevans resedit, quid erga se ageretur miratus est, ac si de gravi somno fuisset excitatus. Quod dum mulier lamentis fatigata conspiceret, coepit ex gaudio magis flere et voces amplius edere" ${ }^{, 140}$.

La mujer está presente, no tiene tampoco un papel importante, es un personaje secundario. La intención del Autor fue presentar el milagro y el monje, gracias al cual, Dios ha hecho eso. Tenemos aquí un retrato de mujer corriente, además pobre, viuda y llorosa. El Santo se sirve de este ejemplo para despertar en los corazones de los lectores el sentimiento de la compasión. Preparado, de ese modo, el lector siente más la grandeza del milagro. Por otro lado, la mujer puede presentarse como un ejemplo del amor a su marido: su llanto es intensivo e imparable. Cuida el cuerpo, no quiere que alguien lo toque.

${ }^{139}$ Hoy la localidad no es conocida.

${ }^{140}$ Dialogi III 17, 3-5, SCh 260, 338-340. 
2.3. La nodriza de S. Benito. Por un diálogo gregoriano nos enteramos que $\mathrm{S}$. Benito tuvo muchos años una nodriza; incluso en los primeros momentos de su vida ascética. Con ella está vinculado el relato siguiente:

\begin{abstract}
„Hic [Benito] itaque cum iam relictis litterarum studiis petere deserta decrevisset, nutrix, quae hunc arctius amabat, sola secuta est. Cumque ad locum venissent, qui Effide dicitur, multisque honestioribus viris caritate se illic detinentibus, in beati Petri ecclesia demorarentur, praedicta nutrix illius ad purgandum triticum a vicinis mulieribus praestari sibi capisterium petiit, quod super mensam incaute derelictum, casu accidente, fractum est, sicque ut in duabus partibus inveniretur divisum. Quod mox ut rediens nutrix illius invenit, vehementissime flere coepit, quia vas quod praestitum acceperat, fractum videbat. Benedictus autem religiosus et pius puer, cum nutricem suam flere conspiceret, eius dolori conpassus, ablatis secum utrisque fracti capisterii partibus, sese cum lacrimis in orationem dedit. Qui ab oratione surgens, ita iuxta se vas sanum repperit, ut in eo fracturae inveniri vestigia nulla potuissent. Mox autem nutricem suam blande consolatus, ei sanum capisterium reddidit, quod fractum tulerat"141.
\end{abstract}

Es una de las pocas mujeres que aparecen en la vida de este padre de los monjes. No cabe duda que en esta narración un tanto fantasiosa, la persona principal es el joven Benito. Sin embargo se puede extraer de aquí algunos aspectos sobre la mujer que le acompañaba. En primer lugar hay que destacar su amor al joven Benito. No sabemos si esa nutrix fue una sierva esclava o libre, pero eso no parece tener gran importancia. Es una mujer honesta que sirve bien y cuida ese servicio. El llanto en el caso del accidente doméstico, no está causado por el miedo o la posibilidad de alguna pena; más parece ser un síntoma de su carácter sincero. Por otro lado, merece atención la relación de Benito con su nodriza y la ayuda que le presta por medio de la oración. No hay que olvidar que siendo un monje Benito no quería tener en su compañía ninguna mujer, incluso tan cercana, y por eso nutricem suam occulte fugiens, deserti loci sucessum petiit, cui Sublacus vocabulum est ${ }^{142}$.

2.4. Una mujer loca. Gregorio está convencido de que la gracia divina, por medio de la intercesión de los santos, puede influir en el hombre, independientemente de su estado psíquico. Para ilustrar mejor esta aserción toma como ejemplo a una mujer:

„Nuper namque est res gesta, quam narro, quia quaedam mulier mente capta, dum sensum funditus perdidisset, per montes et valles, siluas et campos, die noctuque vagabatur, ibique tantummodo quiescebat, ubi hanc quiescere lassitudo coegisset. Quadam vero die, dum vaga nimium erraret, ad beati viri Benedicti patris specum devenit, ibique nesciens ingressa mansit. Facto autem mane, ita sanato sensu

\footnotetext{
${ }^{141}$ Ibidem II 1, 2, SCh 260, 130.

142 Ibidem II 1, 3, SCh 260, 130.
} 
egressa est, ac si eam numquam insania capitis ulla tenuisset. Quae omni vitae suae tempore in eadem, quam acceperat, salute permansit" ${ }^{\text {"143 }}$.

Este texto tiene más sentido hagiográfico que feminista. Es evidente que desde el punto de vista de nuestro Autor tenemos que mirar, más a S. Benito, que a la mujer sanada probablemente, como quiere Gregorio, por su ayuda.

2.5. La doncella paralizada. El objeto de otra curación milagrosa es una joven que estaba en la iglesia de S. Pedro en Roma. Como sacristán servía allí un hombre piadoso llamado Aconcio ${ }^{144}$. En el texto gregoriano encontramos el relato de este prodigio:

„Nam, cum quaedam puella paralitica in eius ecclesia permanens manibus reperet et dissolutis renibus corpus per terram traheret, diuque ab eodem beato Petro apostolo peteret ut sanari mereretur, nocte quadam ei per visionem adstitit, et dixit: «Vade ad Acontium mansionarium et roga illum, atque ipse te saluti restituit». Cumque illa de tanta visione certa esset, sed quis esset Acontius ignoraret, coepit huc illucque per ecclesiae loca se trahere, ut quis esset Acontius investigaret. Cui repente ipse factus est obviam quem quaerebat, eique dixit: «Rogo te, pater, indica mihi quis est Acontius custos». Cui ille respondit: «Ego sum». At illa inquit: «Pastor et nutritor noster, beatus Petrus apostolus, ad te me misit, ut ab infirmitate ista liberare me debeas». Cui ille respondit: «Si ab eo missa es, surge», eiusque manum tenuit et eam in statu suo protinus erexit. Sicque ex illa hora omnes in eius corpore nervi ac membra solidata sunt, ut solutionis illius signa ulterius nulla remanerent" ${ }^{145}$.

En este relato, la figura de la muchacha nos muestra una serie de buenas cualidades: es un el ejemplo de oración constante basada en una fervorosa esperanza. Nos cuenta Gregorio que desde hacía mucho tiempo (diuque), rogaba al patrono de la iglesia que fuera curada. Su encuentro con Aconcio no muestra ninguna duda por parte de la muchacha, en todo se manifiesta muy segura, además Gregorio lo pone de relieve diciendo: „cumque illa de tanta visione certa esset".

2.6. La mujer y el caballo prestado al papa Juan ${ }^{146}$. Aunque en la mayoría de los textos gregorianos analizados en este capítulo tenemos una equilibrada visión de la mujer, sin embargo, algunas veces aparece una opinión también negativa. Escribe Gregorio:

143 Ibidem II 38, 1, SCh 260, 246.

${ }^{144}$ Hay diferentes formas de expresar su nombre, pero parece que se refiere a un santo venerado por la Iglesia y apuntado en el Martirologium Romanum, cfr. A. Codaghengo, Abbondio, BS I 32-33.

${ }_{145}$ Dialogi III 25, 1-2, SCh 260, 364-366.

${ }^{146}$ S. Juan I (523-526), cfr. Dix mille Saints, p. 274. 
„Gothorum tempore, dum Iohannes vir beatissimus, huius Romanae ecclesiae pontifex, ad Iustinum seniorem principem pergeret, in Corinthi partibus advenit. Cui necesse fuit, ut in itinere ad sedendum equus requiri debuisset. Quod illic quidam vir nobilis audiens, equum, quem pro magna mansuetudine eius coniux sedere consueverat, ita ei obtulit, ut, cum ad loca alia pervenienti aptus equus potuisset inveniri, deberet ille, quem dederat, propter suam coniugem retransmitti. Factumque est, et usque ad certum locum praedictus vir, equo eodem subvehente, perductus est. Qui mox ut alium repperit, illum quem acceperat retransmisit. Cumque eum praedicti nobilis viri coniux sedere ex more voluisset, ultra non valuit, quia post sessionem tanti pontificis mulierem ferre recusavit. Coepit namque inmenso flatu et fremitu atque incessanti totius corporis motu quasi despiciendo prodere quia post membra pontificis mulierem ferre non posset. Quod vir eius prudenter intuitus, hunc ad eundem venerabilem virum protinus retransmisit, magnis precibus petens, ut equum ipse possideret, quem iuri suo sedendo dedicasset" ${ }^{147}$.

A primera vista se realza una rara actitud frente a la mujer. El caballo tomado en préstamo por el papa Juan, caminaba tranquilo, y estaba acostumbrado a que fuese montado por una mujer. Es sorprendente la conducta del caballo después de ser devuelto a su dueño. Pero más sorpresiva es la explicación que da Gregorio de ese hecho. El caballo relincha, resopla y sacude su cuerpo como si quisiera afirmar que no puede llevar a la mujer, si antes había llevado a tan gran papa. Y no dice que no podía utilizar al caballo cualquier persona, porque antes le usó un santo, sino que dice directamente, que se trataba de una mujer. La interpretación gregoriana en relación con la mujer hay que entenderla como una manifestación del antifeminismo de la antigüedad.

\section{ALGUNOS OTROS ELEMENTOS DEL CULTO A LAS SANTAS}

Volvemos otra vez a las santas. S. Gregorio, entre las cuestiones concretas, menciona muchas veces algunas cosas que no cuentan directamente sobre la personas, pero describen un testimonio de la religiosidad de su tiempo. En los escritos gregorianos encontramos notas sobre las reliquias o los nombres de las iglesias y monasterios. No hay demasiado de estos textos en el campo femenino, sin embargo, constituyen una pequeña nota complementaria para nuestro tema y por eso hay que referirse también a ellos. Por supuesto, no intentamos dar aquí, la imagen completa del desarrollo del culto de personas concretas o de las obras de arte. Nuestra intención es solamente hacer una simple presentación de su existencia en los textos gregorianos y de las citas que llevan consigo algunas menciones sobre los elementos del culto. 
1. Las reliquias. Un significado grande, desde el principio de la Iglesia, lo tenían las reliquias de los santos. Como entendemos, los ,,restos, con referencia al cuerpo humano o a parte del mismo; en sentido más amplio se llamaban reliquias también los objetos que tuvieron un contacto con una persona que se veneraba"148. El culto de las reliquias en los tiempos de Gregorio estaba ya bastante desarrollado. Desafortunadamente, el mismo Santo no escribe mucho sobre eso. En el primer año de su pontificado envió una carta al obispo Juan de Surrentum, donde dice:

„Religiosis desideriis facile est praebere consensum, ut fidelis devotio celerem
sortiatur effectum. Et quoniam Sabinus abbas monasterii sancti Stephani insulae
Capris suggessit nobis sanctae Agathae martyris reliquias iam olim apud se habere
concessas, et in monasterio suo vult ipsa sanctuaria collocari, ideoque ad praedic-
tum monasterium te iubemus accedere et, si nullum corpus ibidem constat huma-
tum, praedicta sanctuaria sollemniter collocabis, ut devotionis suae potiatur effec-
tu" 149 .

El culto de las reliquias está vinculado a la persona del santo. Es conocido, que las de Sta. Águeda, merecieron un gran honor. Fue una mártir muy afamada ${ }^{150}$. Nuestro Autor utiliza aquí la forma verbal sanctuaria hablando de las reliquias. Esta expresión tiene un amplio significado ${ }^{151}$. Es interesante para nosotros saber, que las reliquías de esta santa, son tan estimados por el Papa. La carta a Juan es un claro testimonio de nuestra opinión sobre S. Gregorio, para quien el nivel de la santidad no depende tanto del sexo de la persona, sino de su conducta y de los valores que representa. Por eso el acto de colocación de las reliquias de Águeda es muy solemne y, hay que subrayar, no menos, que en el caso de las reliquias de algun santo varón ${ }^{152}$.

Sobre las reliquias de esta santa encontramos una mención también en un diálogo, donde nos enteramos del caso de una iglesia dedicada a Sta. Águeda. Con ocasión de restituir allí el culto católico, junto con las reliquias de S. Sebastián, se colocaron allí también los restos de esta santa mártir ${ }^{153}$. Desgraciadamente, la referencia a las reliquias de Sta. Águeda es una de las pocas relacionadas con mujeres. Encontramos unas cortas frases sobre las reliquias de la santa mártir Juliana, junto con las de S. Severino. Es difícil reconocer de cual Sta. Juliana hablan las cartas, pues tenemos varias mártires con este

${ }^{148}$ M. Machejek, Reliquías, en: E. Ancilli (red.), Diccionario de espiritualidad, Barcelona 1984 , t. 3, p. 278.

149 Epistolae I 52, CCL 140, 65.

150 Cfr. G.D. Gordini, Agata, BS I 320-327.

151 Cfr. J. McCulloh, The Cult of Relics in the Letters and Dialogs of Pope Gregory the Great: a Lexicographical Study, ,,Traditio” 32 (1976) 158-165.

152 Cfr. Epistolae IX 49, CCL 140 A, 608; ibidem IX 184, CCL 140 A, 740.

${ }^{153}$ Dialogi III 30, SCh 260, 380-382. 
nombre ${ }^{154}$. El Papa en dos cartas hace sólo pequeñas menciones. En la primera, dirigida al obispo Benenato leemos: „Sanctuaria vero suscepta sui cum reverentia collocabis" ${ }^{155}$. Y en la otra, al obispo Fortunato escribe:

„Ianuaria religiosa femina sanctuaria beatorum Severini confessoris et Iulianae martiris oblata petitione sibi postulat debere concedi, quatenus in eius nomine oratorium propriis constructum sumptibus possit sollemniter consacrari"156.

De ambas cartas resalta su alta estima a las reliquias. Del segundo texto nos enteramos que las reliquias fueron necesarias para la consagración solemne de la capilla.

Es verdad que no tenemos, prácticamente, más menciones de las reliquias femeninas de parte de S. Gregorio. Este hecho puede significar que las reliquias de las santas no eran tan numerosas como las de los martires varones; ni tan populares. La primera opinión podemos fundamentarla en el número de los mártires. Por ejemplo, leyendo las Acta martyrum, entre un gran número de los varones, encontramos apenas unas cuantas mujeres ${ }^{157}$. El fundamento de la menor popularidad, frente al de los restos masculinos, lo podemos también advertir en la posición de la mujer en esos tiempos. Como sabemos „en relación con las concepciones sociales o familiares de la mujer había una serie de ideas y de estereotipos sociales, que estaban en el ambiente y que a pesar de su origen pagano - en muchos casos - eran compartidos por los cristianos ${ }^{158}$.

\section{Nombres de iglesias y monasterios.}

2.1. Sta. Águeda. Mucho mejor se presenta el problema de la mujer en la titulación de las iglesias y monasterios. Nuestro Autor menciona bastantes edificios eclesiales dedicados a santas, por ejemplo las iglesias dedicadas a María. La lista se extiende mucho, si recordamos también las dedicadas a santas extrabíblicas. Ya antes hemos citado a Sta. Águeda. S. Gregorio, sobre esta santa, nos dice que existen iglesias y un monasterio dedicado a ella. Escribiendo al acólito León, nuestro Autor explica:

„Locorum venerabilium cura nos admonetde eorum utilitate per omnia cogitare. Quia ergo ecclesia sanctae Agathae sita in Subura, quae spelunca fuit aliquando pravitatis haereticae, ad catholicae fidei culturam Deo propitiante reducta est, ideoque huius auctoritatis tenore communitus pensiones omnium domorum in hac urbe constitutarum, quas praedicta ecclesia temporibus habuisse Gothorum constiterit, annis singulis congregare non desinas, ut cuantum in sarta tecta vel

${ }^{154}$ Cfr. Dix mille Saints, p. 294.

155 Epistolae IX 181, CCL 140 A, 738.

156 Ibidem IX 182, CCL 140A, 739.

157 Cfr. D. Ruiz Bueno, Actas de los Mártires, Madrid 1951.

158 D. Ramos-Lissón, Aspectos teológicos de la feminidad en S. Ambrosio y S. Agustín, en: Masculinidad y feminidad en la patrística, Pamplona 1989, 126. 
luminaribus aliaque reparatione eiusdem ecclesiae necessarium fuerit, erogare modis omnibus studebis" $" 159$.

Tenemos identificada la Iglesia y el lugar ${ }^{160}$, así como la información de que, en los tiempos de los godos fue usada como templo herético. Ampliando el tema, nuestro Autor, en un pasaje de los Diálogos cuenta sobre su visita en esta iglesia:

„Arrianorum ecclesia, in regione urbis huius quae Subura dicitur, cum clausa usque ante biennium remansisset, placuit ut in fide catholica, introductis illic beati Sebastiani et sanctae Agathae martyrum reliquis, dedicari debuisset. Quod factum est. Nam cum magna populi multitudine venientes atque omnipotenti Domino laudes canentes, eandem ecclesiam ingressi sumus" ${ }^{\text {"161. }}$.

Luego podemos leer que todos han sentido la presencia de un cerdo, aunque no le vieron, que quería salir de la iglesia. Gregorio lo interpreta como el demonio de la herejía, que quería escapar del sitio consagrado. También durante dos noches, en el techo del edificio se podían oír unos fuertes rumores, causados por el demonio echado de la iglesia. La lista de los hechos extraordinarios se completa por una nube, que con un olor muy agradable ha bajado al altar y por las velas, que se encendieron espontáneamente ${ }^{162}$. Como vemos, nuestro Santo no sólo menciona la iglesia de Sta. Ágeda, sino también narra concretamente sobre los sucesos extraordinarios, que allí pasaron.

2.2. Sta. Inés. Inés es otra gran santa mártir, que tiene consagrados edificios de culto, que son citados por S. Gregrorio. Tiene dos homilías pronunciadas en la basílica de su nombre, que están dedicadas a esta santa ${ }^{163}$. La hemos recordado, cuando hablamos del martirio de las mujeres. La misma basílica probablemente fue construida por Constantino el Grande ${ }^{164}$. Además de estas dos homilías, en una carta Gregorio nos habla de una capilla de Sta. Inés en Panormos. Entre otras muchas cosas el Papa menciona a un cierto Anastasio que ,iuxta Panormitana civitate dicitur habitare in oratorio sanctae Agnae" 165 .

159 Epistolae IV 19, CCL 140, 237.

160 Subura, es la parte de la ciudad de Roma situada entre el Palatíno y el Esquilino; cfr. Św. Grzegorz Wielki, Listy, II, Warszawa 1959, p. 28, n. 1. En la misma nota Czuj afirma apoyándose en los Annales ecclesiastici de Baronius que la iglesia fue edificada o reconstruida por el caudillo de los suevos Recimiro, en 472. Hoy es la iglesia Sant'Agata dei Goti.

161 Dialogi III 30, 2, SCh 260, 380.

162 Cfr. ibidem III 30, 3-6, SCh 260, 380-382.

163 Cfr. Homiliae I 11, PL 76, 1114-1118; ibidem I 12, PL 76, 1118-1123; vid. ut supra 3, 2.

164 Cfr. Dix mille Saints, p. 23.

165 Epistolae II 50, CCL 140, 145. 
Encontramos también un recuerdo de Inés, cuando Gregorio escribe al obispo Decio sobre la edificación de un monasterio femenino en las propiedades de una tal Adeodata. La fundadora, como leemos

„,iuris sui intra civitatem Lillibitanam monasterium ancillarum Dei a solo se pro sua devotione fundasse, quod in honore beati Petri principis apostolorum atque sanctorum Christi martyrum laurentii, Ermetis, Pancratii, Sebastiani et Agnes desiderat consecrari” ${ }^{\prime 166}$.

Llama la atención un título del monasterio, dedicado a tantos santos. Merece la pena observar, que Sta. Inés está puesta al lado de cuatro hombres santos, aunque en último lugar. Se podría preguntar: ¿por qué está enumerada como la última de la lista? Todos son santos muy conocidos; puede ser en ese caso una simple casualidad. O también consecuencia de las costumbres sociales de la época que situaban: „primero a los hombres, después a las mujeres”. Estaríamos otra vez ante un reflejo del antiguo antifeminismo. De todas formas no sabemos bien si ésta sucesión de nombres proviene de la misma fundadora, o de nuestro Autor. La cuestión pues queda abierta, ya que no tenemos bastante base para dar una respuesta precisa.

2.3. Sta. Felicidad. Cuando considerábamos el martirio de las mujeres, hemos hablado de una santa mártir llamada Felicidad. La actitud y el significado de esta persona ya la hemos comentado más arriba ${ }^{167}$. Aquí reseñaremos que tenía una basílica bajo su advocación y que Gregorio pronunció una homilía en el día de su martirio ${ }^{168}$. Como nota complementaria, se puede decir que la citada basílica fue edificada por el papa S. Bonifacio (418-422) sobre su sepulcro ${ }^{169}$.

2.4. Sta. Felícula. En la carta de Gregorio a Castorio de Ravena, alude a Sta. Felícula:

„Experientiae tuae in praesenti nos recolis praecepisse ut de possessione, quae monasterio sanctorum Marci, Marcellini et Feliculae, quod Ravennae situm est, largitatis titulo dicitur esse concessa, quia causam bene nosti, debuisses quod iustum est facere" $" 170$.

El Santo amonesta en este pasaje a su notario para que sea más activo en las cosas vinculadas con un monasterio. No vamos a ocuparnos del problema concreto del monasterio que rebasaría nuestro trabajo ${ }^{171}$. Tenemos pocos datos sobre Sta. Felícula, que fue una santa mártir de Roma. No conocemos la fecha concreta de su muerte, pero probablemente, fue martirizada en el

\footnotetext{
${ }^{166}$ Ibidem IX 233, CCL 140 A, 815.

167 Vid. ut supra 3, 1.

168 Cfr. Homiliae I 3, PL 76, 1086-1089.

169 Cfr. F. Caraffa, art. cit., col. 606.

170 Epistolae IX 169, CCL 140A, 727-728.

171 Cfr. ibidem VI 1, 28.
} 
I siglo ${ }^{172}$. El testimonio gregoriano es uno de los más importantes en relación con su culto.

2.5. Sta. Juliana. Nuestro Autor atestigua también el culto de Juliana, mártir. Es difícil determinar quien era la que respondía a ese nombre, como ya hemos dicho antes, analizando el tema de las reliquias ${ }^{173}$. Nuestro Santo hace mención de esta santa en cuatro cartas. De dos de ellas nos hemos ocupado más arriba, cuando hablábamos de un oratorio dedicado para S. Severino y Sta. Juliana mártires ${ }^{174}$.

Pero, además de estas referencias, tenemos otro testimonio del culto a esta santa; pues Gregorio habla también de un monasterio dedicado a ella. En una de las cartas dirigida a Romano, defensor ${ }^{175}$ de Sicilia, al referirse a un monasterio y a sus problemas jurídicos, indica el nombre de Juliana entre los titulares de esa casa religiosa:

„Fuscus abbas monasterii sanctorum Erasmi, Maximi atque Iulianae, quod Neapolim ab Alexandria clarissimae memoriae femina, sicut nosti, fundatum est" ${ }^{\text {"176 }}$.

En esta breve nota, el Papa atestigua el nombre de la fundadora, el sitio y ante todo el título. También aquí el nombre de la santa va al final, después de los varones. El mismo monasterio se menciona también en otra carta: „Fuscus abbas monasteriorum [...] sanctorum Maximi, Erasmi et Iulianae"177, con el mismo orden de los nombres de los santos.

2.6. Sta. Lucía. Hay también otro monasterio masculino dedicado a Sta. Lucía, en Siracusa. En el texto correspondiente, Gregorio alude a una querella entre dos abades; uno de ellos ,....monastrii sanctae Luciae in Syracusana civitate constitutum"178. Seis años después, nuestro Autor escribió otra carta al mismo obispo Juan de Siracusa, donde menciona a un sacerdote, que antes fue „monacho monasterii sanctae Luciae" ${ }^{179}$. En ambas cartas tenemos solo estas palabras. No es poco. El nombre del monasterio dice mucho. Nos enteramos que existió tal monasterio, atestiguando la devoción a Sta. Lucía. Al margen, se puede afirmar, que no es sorprendente la existencia de un edificio religioso dedicado a esta santa, porque por su martirio estaba muy relacionada con esa ciudad $^{180}$. El culto de esta mujer se desarrolló también en Roma. Así en

${ }^{172}$ Cfr. A. Amore, Felicola, BS V 612-613.

173 Vid. ut supra 6, 1.

174 Cfr. Epistolae IX 181.182, CCL 140A, 738-739.

175 Los defensores eran unos funcionarios que actuaban como abogados, y luego como representantes papales con diversos cometidos, cfr. A. Di Berardino, Defensor, DPAC II 560-570.

176 Epistolae IX 171, CCL 140A, 729.

177 Ibidem IX 173, CCL 140A, 730.

178 Ibidem VII 36, CCL 140, 499.

179 Ibidem XIII 30, CCL 140A, 1031.

180 Cfr. A. Amore, Lucia, BS VIII 241-252 
una carta sobre unos problemas jurídicos, el Papa habla de Probo, que fue „abbas monastrii sanctorum Andreae et Luciae”181. La unión de esas dos santas personas en el mismo título es significativa, porque atestigua la grandeza de Sta. Lucía a los ojos de los cristianos de ese tiempo, ya que la consideran digna de estar al lado de un gran apóstol.

2.7. Sta. Sab(v)ina. Nuestro Autor, en la basílica de Sta. Sabina, anunció la letanía con las procesiones penitenciales en „Denuntiatio pro septiformi letania"182. También recuerda los "grados sancte Sabinae"183. Al mismo tiempo hace una mención del titulus Sabinae. Esas son las únicas palabras de Gregorio sobre la veneración de esta santa. Tenemos testimonios más antiguos de la existencia de ese edificio ${ }^{184}$. Los datos aportados por Gregorio atestiguan el uso de la basílica por el Papa y de este modo, indirectamente, el culto a Sta. Sabina.

2.8. Sta. Cecilia. Por último, podemos mencionar también la iglesia dedicada a Sta. Cecilia ${ }^{185}$. S. Gregorio en la mencionada „Denuntiatio pro septiformis letania” se refiere a esta iglesia, mandando que salga ,letania pauperum et infantium ab ecclesia beatae martyris Caeciliae"186. Nuestro Santo hablando sobre ese hecho, sirve como testigo del uso de esta antigua iglesia romana y del culto de su santa patrona.

3. Los tituli. Otra fuente que nos informa sobre advocaciones de santas aparece en el uso de los „títulos” de las iglesias. Concretamente en un lugar de sus Cartas se menciona a los sacerdotes de esos tituli. Allí podemos enterarnos de los nombres de las siguientes personas:

„Andromacus presbyter tituli Eudoxiae, Rusticus presbyter tituli sanctae Susannae, (...) Agapitus presbyter tituli sanctae Eudoxiae, Felix presbyter tituli sanctae Sabinae, ${ }^{, 187}$.

El testimonio de nuestro Autor tiene su interés, aunque sea una pequeña referencia para los historiadores de la Iglesia y de la liturgia ${ }^{188}$.

181 Epistolae XI 15, CCL 140A, 881.

182 Cfr. ibidem, Appendix 9, CCL 140A, 1104.

183 Ibidem II 46, CCL 140, 138.

184 Cfr. A. Amore, Sabina e Serapia, BS XI 540-542: „Durante il pontificato di papa Celestino I (422-432) il presbitero illirico Pietro edificó sull'Aventino una basilica, che nei documenti del sec. V (sinodo del 499) é detta ,titulus Sabinae”, mentre in quelli del sec. VI (sinodo del 595 e „Liber Pontificalis"), secondo un uso ben noto agli estudiosi é chiamata „titulus sanctae Sabinae”.

${ }^{185}$ Famosa mártir al fin del siglo II o en los primeros años del III, cfr. E. Josi, Cecilia, BS III 1064-1081.

186 Epistolae, Appendix 9, CCL 140A, 1104.

187 Ibidem XI 15, CCL 140A, 881. Czuj alega también un decreto sinodal de los tiempos gregorianos, donde se menciona además otros ,títulos”, como los de Sta. Balbina, Sta. Cecilia, Sta. Práxedes, Sta. Prisca, cfr. Św. Grzegorz Wielki, Listy, II, Warszawa 1954, 156. 
La visión gregoriana de la mujer es sorprendentemente diferente a la imagen que nuestro Autor da a conocer, basándose en los ejemplos bíbli$\cos ^{189}$. Allí la mujer está muchas veces presentada de forma negativa, como alguien sometido a diversas carencias. Durante el análisis de los ejemplos hagiográficos y legendarios, así como mirando a algunos elementos del culto cristiano, hemos descubierto una imagen más positiva y entonada con la realidad.

1. La mujer en el terreno de la santidad es prácticamente igual al hombre; en la santidad, lo que cuenta, no es el sexo sino, el grado de vida espiritual que se alcanza. En consecuencia, el camino de la santidad y lógicamente el de la salvación, de ningún modo está cerrado para la mujer: ella va al cielo del mismo modo que el hombre. La mujer es digna de recibir los dones divinos, como profecía o incluso ser participante de las teofanías. Esa igualdad, la observamos también, a la hora de expresar la veneración a los santas en los títulos de las iglesias y otros edificios eclesiásticos mencionados por Gregorio o edificados en su tiempo.

2. Los exempla femeninos son equiparables a los masculinos en todos sus efectos. Confirman esta opinión los ejemplos de las mártires cristianas que llevan consigo un gran significado parenético y ascético. Desde esta perspectiva, la persona santa, es como un indicador que enseña el camino de la perfección cristiana, sin diferencia entre hombres y mujeres. En los textos gregorianos hemos hallado ejemplos femeninos verdaderamente heroicas, de esperanza cristiana y de caridad tanto para con Dios, como para con el prójimo.

3. Al lado de las virtudes cardinales también, por supuesto, encontramos claros ejemplos de las virtudes propiamente femeninas, como el amor maternal. En este sentido es preciso resaltar la ejemplaridad de una mártir, Sta. Felicidad, madre de siete hijos y testigo de su martirio. Es una verdadera madre que quiere para sus hijos el bien supremo, no sólo el terrenal.

4. La mujer en el modo de vivir su caridad puede sobrepasar espiritualmente al varón, incluso tratándose de un gran santo, como describe Gregorio en el caso de Escolástica y Benito.

Al hacer balance de este capítulo no se deben omitir algunos aspectos negativos de la visión de la mujer y que están presentes en los escritos de Gregorio, como podemos leer en el caso legendario del caballo que no quería llevar a su dueña, porque antes había llevado al papa Juan I y ahora, no podría

${ }^{188}$ Más amplia elaboración del tema de los tituli podemos encontrar en: M.A. Crippa - J. Ries - M. Zibawi, El arte paleocristiano. Visión y espacio de los orígenes a Bizancio; Barcelona - Madrid 1998, 46-47; J.A. Iñiguez, Síntesis de arqueología cristiana, Madrid 1977, 101-104.

189 Como ya hemos señalado, en otro tiempo vamos a publicar un artículo especial sobre esta cuestión. 
mancharse, llevando a una mujer. También en los casos de las mártires se puede encontrar algunos elementos menos apreciativos de la mujer, como cuando se aplican a la mujer virtudes de corte varonil.

\section{HAGIOGRAFICZNE I LEGENDARNE PRZYKŁADY KOBIECE ORAZ NIEKTÓRE ELEMENTY KULTU ŚWIĘTYCH KOBIET W DZIEŁACH ŚW. GRZEGORZA WIELKIEGO}

\section{(Streszczenie)}

Jeśli wśród dzieł św. Grzegorza Wielkiego chcemy odnaleźć wizerunek świętej kobiety, ograniczając przy tym naszą wizję jedynie do postaci pozabiblijnych, praktycznie cały materiał odnajdziemy w dwóch dziełach, tj. w Homiliach na Ewangelie i w Dialogach. wedle nagromadzenia materiału i wagi nadanej mu przez samego Grzegorza, najpierw znajdujemy kilka przykładów świętych z jego własnej rodziny, przede wszystkim ciotek, które wybrały drogę życia zakonnego (św. Emiliana i św. Tarsylia). W ich cieniu odnajdujemy jedno jedyne zdanie, w którym wspomina swą matkę, św. Sylwię. Nie wydaje się to dziwne, jeśli zważymy, iż nasz Autor zdecydowanie mniej cenił stan małżeński niż zakonny, który uważał za zaślubiny duchowe z Chrystusem. W tejże perspektywie kolejnymi świętymi przezeń przedstawionymi jawią się mniszki i dziewice, przede wszystkim zaś św. Scholastyka. Nie brak miejsca dla męczennic, jak św. Felicyta i Agnieszka. Te dwie grupy mają zresztą wspólną cechę - w ujęciu bowiem Grzegorzowym istnieją dwa rodzaje męczeństwa: fizyczne i duchowe. Obok świętych uznanych przez Kościół, spotykamy u Grzegorza grupę kobiet legendarnych, które niosą ze sobą parenezę, tak typową dla naszego Autora. Kobiety te są przykładami wytrwałości, miłości matczynej i małżeńskiej, ufności w Bożą pomoc, aczkolwiek są czasem postaciami drugoplanowymi i tłem dla ukazania świętości postaci męskich.

Wśród dzieł Grzegorza spotykamy także kilka historycznych świadectw czci kobiecych relikwii i używania imion świętych kobiet w tytułach świątyń i klasztorów. Fragmenty te zwykle mają znaczenie drugorzędne, choć np. w przypadku św. Felikuli świadectwo Grzegorza jest jednym z ważniejszych. Kobieta w oczach Grzegorza może być wzorem świętości, miłości, nadziei, otrzymuje dary Boże, na płaszczyźnie relacji z Bogiem jest nawet w możności przewyższyć mężczyznę: Ta umiarkowana wizja traci jednak nieco swój blask, jeśli uwzględnimy takie np. opinie, że koń, którego wcześniej dosiadał jeden z poprzedników świętego, nie chcąc się splamić, nie pozwolił by go dosiadła kobieta, lub że w ciele św. Felicyty, słabej kobiety, znajdujemy jednak „męskie serce”. Nie sposób uniknąć konkluzji że choć owa słaba kobieta mogła być w oczach Wielkiego Papieża ewidentnym przykładem świętości chrześcijańskiej, to sam Grzegorz był typowym reprezentantem swej epoki, z jej bagażem uprzedzeń, chociaż i tak okazuje się znacznie delikatniejszy od niektórych wcześniejszych pisarzy. 